\title{
Advances in Antibacterial Functionalized Coatings on Mg and Its Alloys for Medical Use-A Review
}

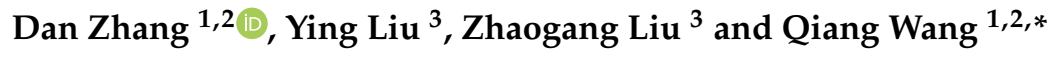 \\ 1 School of Stomatology, China Medical University, Liaoning Provincial Key Laboratory of Oral Diseases, \\ Shenyang 110002, China; zdcmu888@outlook.com \\ 2 Department of Central Laboratory, School of Stomatology, China Medical University, \\ Shenyang 110002, China \\ 3 School of Stomatology, Jiamusi University, Jiamusi 154007, China; liuyingsee@163.com (Y.L.); \\ lzglly2011@163.com (Z.L.) \\ * Correspondence: mfqwang@cmu.edu.cn
}

Received: 15 July 2020; Accepted: 25 August 2020; Published: 27 August 2020

check for updates

\begin{abstract}
As a revolutionary implant material, magnesium and its alloys have many exciting performances, such as biodegradability, mechanical compatibility, and excellent biosecurity. However, the rapid and uncontrollable degradation rate of magnesium greatly hampers its clinical use. Many efforts have been taken to enhance the corrosion resistance of magnesium. However, it must be noted that improving the corrosion resistance of magnesium will lead to the compromise of its antibacterial abilities, which are attribute and proportional to the alkaline $\mathrm{pH}$ during its degradation. Providing antibacterial functionalized coating is one of the best methods for balancing the degradation rate and the antibacterial ability of magnesium. Antibacterial functionalized magnesium is especially well-suited for patients with diabetes and infected wounds. Considering the extremely complex biological environment in the human body and the demands of enhancing corrosion resistance, biocompatibility, osteogenesis, and antibacterial ability, composite coatings with combined properties of different materials may be promising. The aim of this review isto collect and compare recent studies on antibacterial functionalized coatings on magnesium and its alloys. The clinical applications of antibacterial functionalized coatings and their material characteristics, antibacterial abilities, in vitro cytocompatibility, and corrosion resistance are also discussed in detail.
\end{abstract}

Keywords: antibacterial functionalized coating; magnesium; corrosion resistance; polymer-based coatings; HA-based coatings

\section{Introduction}

$\mathrm{Mg}$ and its alloys have attracted great attention recently for excellent behaviors on biodegradability, mechanical compatibility that is well-matched with the human bone, and biological safety with osteogenesis effects [1-3]. Among all these advantages, biodegradability is the most alluring property for the application of magnesium as medical appliances. Many studies have been taken to investigate magnesium as biodegradable orthopedic or cardiovascular temporal implants [4-6]. However, the rapid degradation rate in the physiological environment greatly hampers its clinical use. The rapid and uncontrollable corrosion process leads to a significant decrease in mechanical strength of the orthopedic appliance, and finally results in the premature failure of the implants. Many efforts have been taken to enhance the corrosion resistance of magnesium [7-11]. However, it must be taken into account that improving the corrosion resistance of magnesium will lead to the compromise of its antibacterial abilities, which are attribute and proportional to the alkaline $\mathrm{pH}$ during its degradation [12-14]. For most of the bacteria, the optimum growth environment is around $\mathrm{pH}$ 7.2-7.6. When the surrounding $\mathrm{pH}$ exceeds 
the tolerance of the bacterial, the bacteria will lose activity and even go dead [15]. Ren et al. showed that pure $\mathrm{Mg}$ indicated higher antibacterial activity than $\mathrm{Mg}$ coated with porous silicon, because the $\mathrm{pH}$ of the coated samples had nearly no change [16].

Infection is one of the most severe postoperative complications. With the increasing of traffic accidents and the growing number of complex orthopedic surgeries, perioperative infection control has attracted great attention over recent years. The formation of bacterial biofilm triggered by bacterial adhesion and colonization is recognized as the pathogenic factor of peri-implantitis, leading to the loss of implants. However, once the bacterial biofilm is formed, it is very hard to be removed by the body's immune system. Therefore, providing magnesium with proper antibacterial ability to prevent biofilm formation is an effective way to avoid peri-implantitis. Coating with antibacterial elements is one of the best methods to obtain favorable antibacterial properties. Many efforts have been taken to apply proper antibacterial coatings on magnesium. Zhou et al. modified magnesium by a Zn-doped nanowhisker hydroxyapatite coating and found that the nanowhisker coating significantly improved the corrosion resistance and the antibacterial activity of magnesium [17]. In the study of Zou et al., a zinc-loaded montmorillonite coating revealed good corrosion resistance and antibacterial ability on magnesium alloy AZ31 [18]. Ji et al. evaluated the corrosion resistance and antibacterial property of a hydroxyapatite coating on magnesium alloys induced by gentamicin-loaded polymeric multilayers and got definite conclusions in their study [19]. Song et al. also revealed the excellent antibacterial property and biocompatibility of a composite ultrasonic micro-arc oxidation phytic acid copper-loaded coating on pure magnesium [20].

Many antibacterial ingredients were adopted to enhance the antibacterial properties of the coatings on magnesium and its alloys. Most of the research studies were carried out by adding antibiotics [21-23] or antibacterial metallic elements (silver, copper, zinc, etc.) [24-26] into polymer coatings [27-30] or calcium phosphates (Cap) coatings [31,32]. Furthermore, many physical and chemical surface modification strategies, such as dipping, plasma electrolytic oxidation (PEO), Lay-by-Lay (LbL) assembly, and Sol-Gel, were adopted to enhance the combination properties of the antibacterial coatings. The aim of this review is to collect and compare studies on the antibacterial functionalized coatings of magnesium and its alloys. Medical applications of antibacterial magnesium and the material characteristics of the mainstream antibacterial functionalized coatings are compared elaborately. An overview of the antibacterial abilities, the in vitro cytocompatibility, and the corrosion resistance of different antibacterial functionalized coatings are also taken in this article.

\section{Medical Applications of Antibacterial Functionalized Magnesium-Based Materials}

\subsection{Antibacterial Functionalized Magnesium Alloys Used as Orthopedic Appliances}

The history of metallic materials as medical implants can be traced to the nineteenth century. A large number of wounded soldiers needed surgery, which greatly improved the clinical application of metallic orthopedic appliances. Nowadays, metallic materials are progressively used in bone-related traffic accident treatments and tumor therapy. As a revolutionary implant material, magnesium has many perfect properties compared with traditional orthopedic appliances. The most attractive feature is biodegradability, which provides magnesium-based materials the advantage of avoiding secondary surgeries to remove the implant material. Besides biodegradability, magnesium is light in weight and low in density. As a material with a high strength/weight ratio, magnesium also has the advantage of having a similar elastic modulus to human bone to avoid stress-shielding effects caused by the much larger elastic modulus of the traditional orthopedic materials. In the year of 2013, the MgYREZr alloy system received approval from the Conformité Européene (CE) for human application and presented satisfying results in the following clinical study [33].

Infection is reported to be the most severe and devastating complication associated with biomaterials [34]. Currently, the global infection risk is 2-5\% in orthopedic surgery [35]. In patients with diabetes, peri-implant inflammation is one of the primary causes of the loss of implantation 
materials [36,37]. Infection will lead to inflammation of the surrounding tissue and loosing of the implanted materials. Further treatments, even additional surgery, would be taken if the infection is out of control. Bacterial adhesion and biofilm formation are the first steps in bacterial colonization leading to bone infection. Theoretically, all medical devices are susceptible to microbial colonization and infection, although routing anti-infection measurements are taken for every patient. However, the bacterial biofilm was difficult to be removed by immune systems and insensitive to antibiotics. Preventing the formation of a biofilm is a promising method to avoid bacterial infection around the implants. With the increase of traffic accidents and the demand for complex orthopedic surgery, the antibacterial property has become one of the most important features for the clinical application of magnesium as orthopedic appliances. The antibacterial property is extremely important for patients with infected wounds. The clinical use of antibacterial-functionalized magnesium would greatly expand the clinical application range of magnesium and decrease post-operated treatments in the long run. As it has been known, the antibacterial property of magnesium was caused by the alkaline environment generated by its degradation. However, the in vivo antibacterial abilities of magnesium were controversial. As we all know, the human body is one of the most accurate buffer systems, which will neutralize the $\mathrm{pH}$ value around the implant within a few minutes. Besides, the in vivo corrosion rate of magnesium was, in general, lower than that obtained in vitro [38]. The in vitro and in vivo antibacterial abilities of pure $\mathrm{Mg}$ were compared by Hou et al. [39]. They found that the antibacterial property of $\mathrm{Mg}$ showed a significant decrease in rat femurs compared to that in the in vitro test.

As an ideal biodegradable material that is easy to corrode in the human body without generating any toxic products, magnesium has been recognized as one of the most suitable candidate materials for orthopedic appliances. Many efforts have been taken to improve both the corrosion resistance and the antibacterial ability of magnesium. In our previous study [40], a series of copper-bearing PEO coatings were fabricated on pure magnesium to evaluate the antibacterial ability, biocompatibility, and corrosion resistance of the newly orthopedic material. The results revealed that adding a proper amount of $\mathrm{CuO}$ into PEO coatings could greatly improve the antibacterial abilities of the PEO coatings. The antibacterial activities of copper-bearing PEO coatings were excellent and revealed as concentration-dependent and time-dependent. Different concentrations of graphene oxide/silver nanoparticles were introduced into poly-L-lactic acid fibrous to enhance the corrosion resistance and antibacterial performance of magnesium [41]. Compared with the uncoated $\mathrm{Mg}$ alloy, the antibacterial coating significantly improved the antibacterial ability against both Escherichia coli (E. coli) and Staphylococcus aureus (S. aureus).

However, there is still a long way to go for the clinical application of magnesium-based antibacterial appliance. Firstly, in vivo studies on antibacterial magnesium are rare and lack cross-study. Although many studies have been taken to enhance the antibacterial abilities of magnesium, the results of these studies still lack of comparability due to different experimental methods and a lack of judgement standards. Secondly, the clinical application of antibacterial appliance depends on the purpose of clinical demands and the risk of infection. The antibacterial magnesium alloys would not totally take the place of traditional magnesium-based biomaterials. For the orthopedic appliances implanted in the infected wounds, drug-loading magnesium would be a good choice. For the purpose of preventing postoperative infections, antibacterial metallic ion-coated magnesium alloys would be better. Thirdly, as an orthopedic material, antibacterial magnesium would be used under stress states. The degradation performance under stress should also be considered. Fourthly, the complexity of the manufacturing process and the fabricating cost also affects the development of antibacterial-functionalized magnesium. Further studies should focus on the in vivo degradation performance and the development of multilayer coatings.

\subsection{Antibacterial-Functionalized Magnesium Alloys Used as Cardiovascular Stents}

Besides being used as orthopedic appliances, magnesium $(\mathrm{Mg})$-based cardiovascular stents have been recognized as a novel approach in coronary stent technology [42]. Clinical trials on the first 
generation of the bioabsorbable metal stent AMS-1 (Biotronik, Berlin, Germany), which was made of WE 43, showed a good safety profile. However, AMS-1 underwent nearly complete degradation within four months after implantation [38]. Based on AMS-1, drug-eluting stents DREAMS 1G and DREAMS $2 \mathrm{G}$ with drug-loading polymer coatings were developed, exhibiting slower degradation and better safety profiles $[43,44]$.

Unlike being used as orthopedic appliances, drug-loading magnesium-based cardiovascular stents should have the following properties. Firstly, the degradation rate of cardiovascular stents should be slower than that of the orthopedic appliance, which should be six months or longer to provide excellent support for the vascular. Secondly, the drug-releasing rate of antibiotics should be slow and sustained. In contrast, the antibacterial effects of the orthopedic appliance should be fast and efficient. Thirdly, the surrounding environment of a coronary stent is significantly different from that of the orthopedic device. The liquid environment and the scour of blood flow greatly influenced the degradation behavior of magnesium. Therefore, the coatings on magnesium-based cardiovascular stents are mostly multilayer, and the base materials of the coatings are mostly different kinds of polymers. Ma et al. fabricated sirolimus-eluting dextran and polyglutamic acid hybrid coatings on AZ31 for stent applications. They demonstrated that such a three-layer hybrid coating was useful to improve the vascular biocompatibility of $\mathrm{Mg}$ stent materials. In their study, biodegradable and nontoxic polymers, dextran, and polyglutamic acid (PGA) were used to fabricate protective coatings on $\mathrm{Mg}$ alloy AZ31 [45]. For the three-layer design, the first and third dextran layers served as the matrix and reservoir, and the middle PGA layer was used as the rate-controlling material. Moreover, the degradation product, glutamic acid, had the potential of neutralizing the increasing $\mathrm{pH}$ during the degradation of AZ31. For the further clinical use of magnesium for cardiovascular stents, the releasing control of the antibiotics, the binding strength between different functional layers, and the corrosion behavior under the circulation environment are the focus of concern.

\section{Antibacterial Functionalized Coatings on Magnesium}

A protective coating is an effective way to improve the corrosion resistance of magnesium and its alloys. Many technologies, such as thermal spraying [46], chemical conversion, and biomimetic approaches $[47,48]$, can obtain the protective coatings. To further enhance the antibacterial abilities of the protective coatings, antibacterial elements were introduced and effectively used in antibacterial functional coatings on magnesium alloys. A wide variety of antibacterial mechanisms were exhibited in the application of antibacterial coatings, such as destruction of the bacterial membrane, blocking DNA replication, blocking ATP synthase, preventing cell respiration, and interrupting protein synthesis. As an "active" material with high reactivity and a relatively low melting point $\left(650^{\circ} \mathrm{C}\right)$, the coating protocols of magnesium are more complicated than traditional orthopedic materials. In order to combine protective coatings and antibacterial elements, composite coatings and multilayer coatings are widely adopted in functional antibacterial coatings on magnesium.

\subsection{Polymer-Based Antibacterial Functionalized Coatings}

With the performances of biodegradable, biocompatibility, drug delivery, self-healing, and osteogenesis, polymer coatings have been the focus of concern for the protective coatings on magnesium alloys. Biodegradable polyesters poly lactic acid (PLA), poly glycolic acid (PGA), poly lactic acid-co-glycolic acid (PLGA), and their copolymers have been demonstrated to have promising properties in clinical uses [49-51]. For the reported approaches of adding antibacterial elements into Mg alloy coatings, polymer coatings with antibiotics or inorganic antibacterial ions are the most frequently used methods.

\subsubsection{Polymer-Based Coatings Combined with Antibiotics}

Many biodegradable polymers were used as drug reservoirs $[52,53]$ in medical treatments such as cardiovascular stents, drug delivery systems, and tissue regeneration scaffolds [54-56]. To further improve the corrosion resistance, antibacterial property, biocompatibility of the magnesium, and control 
the drug release rate, multilayer functional coating is the direction of future development. The bonding strength between the different layers, polymer, and the base magnesium alloys, along with the releasing burst of the antibiotics, are the most serious problems in the appliance of drug-loaded polymer coatings on magnesium.

As an antibiotic widely used to prevent implant-related infections [57], gentamicin sulfate (GS) is the most frequently used antibiotic to fabricate polymer-based antibacterial coatings on magnesium for orthopedic use. Zhao et al. [58] evaluated the corrosion resistance and drug release profile of gentamicin-loaded polyelectrolyte multilayers (PEMs) on magnesium alloys and concentrated on the effects of heat treatment for the first time. Positively charged allylamine hydrochloride (PAH) [59] and negatively charged polyacrylic acid (PAA) [60] were selected to form polyelectrolytes onto AZ31 magnesium alloys in their study, and gentamicin sulfate (GS) was incorporated into the PEMs to improve the antibacterial properties of the substrate [61,62]. Crosslinking between the polyelectrolytes was achieved by heat treatment to enhance the binding between GS and other charged assembly units.

Magnesium (Mg)-based cardiovascular stents are a promising candidate as the next generation of novel stents. As a macrolide antibiotic with excellent immunosuppressive effects, sirolimus, also called rapamycin, was the most frequently used antibiotic for cardiovascular stents. A double-layer coating of PCL and PDLLA was fabricated on AZ31 by Xu et al. to combine the advantages of good corrosion resistance and satisfied drug-releasing speed [63]. They compared poly ( $\varepsilon$-caprolactone) (PCL), poly (D, L lactide) (PDLLA), and poly (D, L-lactide-co- $\varepsilon$-caprolactone) (PLCL) to examine the capability of these polymers on releasing sirolimus (SRL). Among these polymers, the PDLLA polymer exhibited the slowest release and the best character as a drug reservoir. However, the corrosion resistance of PDLLA was as poor as an uncoated platform. To combine the advantages of each polymer, a precoating of PCL or PLCL was applied to the interface between the platform and the external SRL-loaded PDLLA layer. The in vitro and in vivo degradation of rapamycin-eluting $\mathrm{Mg}-\mathrm{Nd}-\mathrm{Zn}-\mathrm{Zr}$ alloy stents in porcine coronary arteries was evaluated by Shi et al. with the purpose of using them as drug-eluting stents for patients with coronary artery disease [64]. A rapamycin-eluting poly (D, L-lactic acid) coating (PDLLA/RAPA) was prepared in their study; with a three-months follow-up, they found that the PDLLA/RAPA-coated Mg-Nd-Zn-Zr alloy stents showed favorable safety and gratifying neointima formations.

\subsubsection{Polymer-Based Coatings Combined with Antibacterial Ions}

Metal elements such as silver, copper, $\mathrm{Zn}$, and tin have been introduced to enhance the antibacterial properties of magnesium $[21,58,65]$. The bactericidal activity of these ions seems to depend on their gradual release from specimens into surrounding tissues. In the study of Zhao et al., silver nanoparticles (AgNPs) and polymethyltrimeth-oxysilane (PMTMS) were introduced into AZ31 Mg alloys via layer-by-layer (LbL) assembly and a siloxane self-condensation reaction [66]. Yang et al. introduced copper-bearing bioactive glass nanoparticles into polycaprolactone coating systems to improve the bioactivity, antibacterial property, and corrosion resistance of magnesium matrices and thoroughly compared different amounts of Cu-BGNs (1, 3, and 5 wt.\%) in PCL coatings in their study [67]. Metallic oxides have also been demonstrated to have antibacterial capabilities. Rau et al. added $5 \mathrm{wt} . \% \mathrm{CuO}$ into bioactive glass in their study and found that the CuO-contained material showed excellent antibacterial abilities, and the antibacterial abilities revealed were more effective against Gram-negative bacteria (Pseudomonas aeruginosa, Escherichia coli, and Salmonella enterica) rather than against Gram-positive bacteria (Staphylococcus aureus) [68].

The exact biological effects of antibacterial ions on the activity of microorganisms are still unclear. Among all the hypotheses, the antibacterial mechanisms of silver and copper receive the most recognition. As an excellent antimicrobial agent, silver possesses the ability of inhibiting the growth of both Gram-positive and Gram-negative bacteria without the risk of antibiotic resistance [69-71]. $\mathrm{Ag}$ is well-tolerated by the body. The maximum cytotoxic concentration of Ag toward human cells is $10 \mathrm{ppm}$ [72]. The antibacterial effects of silver ions generally depend on its concentration 
and sustainability. However, the exact antibacterial mechanism of silver ion is still indeterminate. The schematic illustration on the antibacterial mechanics of silver-implanted polymer coatings is shown in Figure 1. Studies have shown that $\mathrm{Ag}^{+}$can penetrate the bacterial cell membrane by ion exchange with the cell envelope proteins. Silver ion can penetrate the cell membrane of bacteria. After entering the bacteria, silver ions can kill the bacteria in two primary ways: (1) Silver ion can strongly bind to the thiol groups of vital enzymes in the bacteria and cause bacteria apoptosis. (2) Silver ions can also bind to the DNA molecules of the bacteria, which causes an increase in mutation rates and replication errors during DNA duplication, leading to a reduced replication efficiency and slower replication rates [73-75].

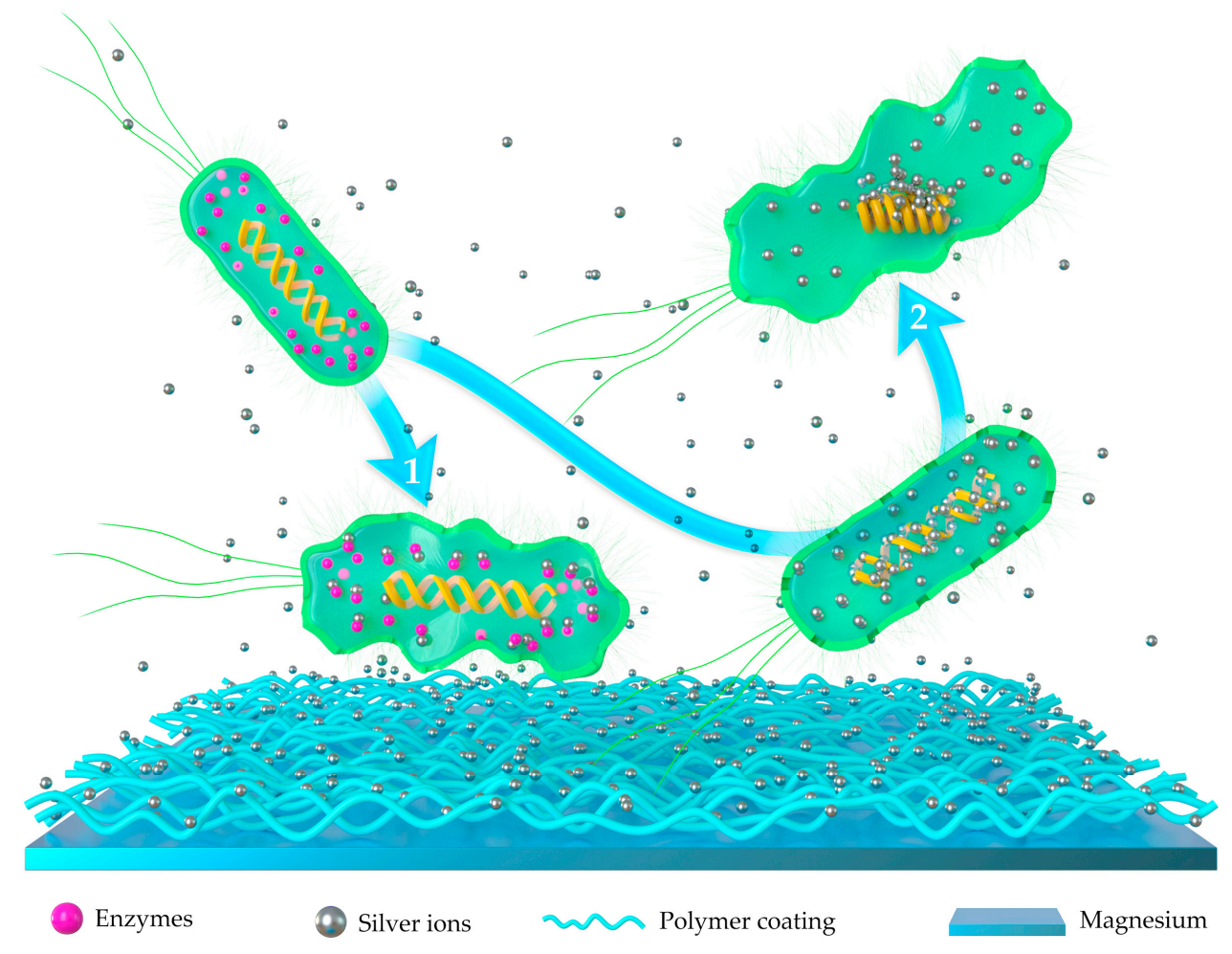

Figure 1. Schematic illustration of antibacterial mechanical silver ion-implanted polymer coatings. Silver ion can penetrate the cell membrane of bacteria. After entering the bacteria, silver ions can kill the bacteria in two primary ways: (1) Silver ion can strongly bind to the thiol groups of vital enzymes in the bacteria and cause bacteria apoptosis. (2) Silver ions can also bind to the DNA molecules of the bacteria, which causes an increase in mutation rates and replication errors during DNA duplication, leading to a reduced replication efficiency and slower replication rates.

As an essential element of the human body, copper has been registered as the first effective metallic antibacterial material by the U.S. Environmental Protection Agency. Copper is considered to have the effect of killing 99.9\% of bacteria within $2 \mathrm{~h}$. As shown in Figure 2, the possible antibacterial ways of copper ions are as follows: (1) $\mathrm{Cu}$ ions can be adsorbed onto the bacteria membrane through electrostatic action, which limits the activity of bacteria, inducing metabolic disorders and cell death [76]. (2) Cu ions can penetrate the bacteria membrane into the cells, which destroys the membrane integrity and leads to leakage of the cytoplasm and cell death. (3) Cu ions can disrupt the activity of respiratory chains and disturb the process of gene replication of the bacteria. (4) $\mathrm{Cu}$ ions can lead to the damage of the central catabolic and biosynthetic pathways by oxidative stress injury [77]. 


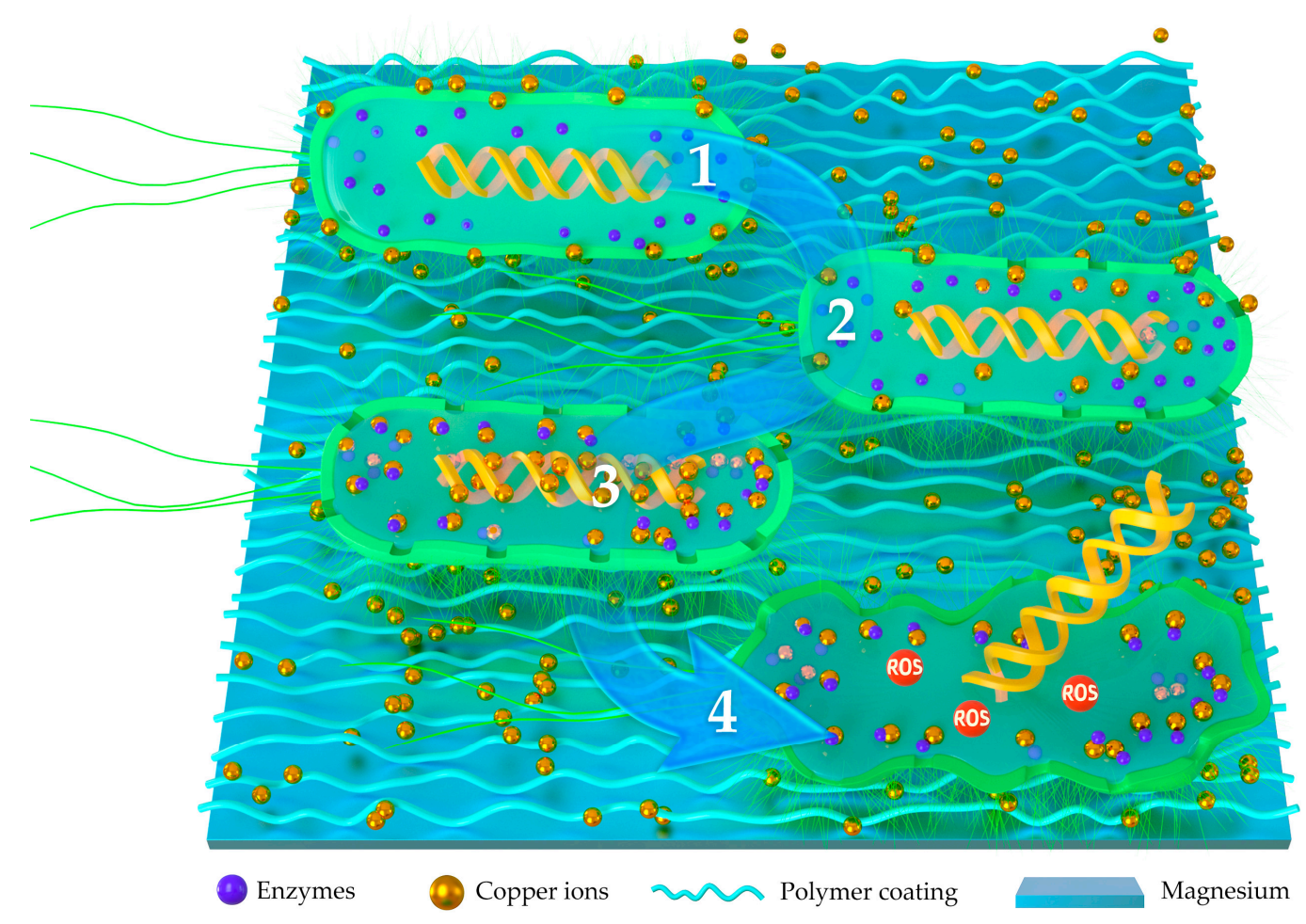

Figure 2. Schematic illustration of antibacterial mechanical copper-implanted polymer coatings. (1) $\mathrm{Cu}$ ions can be adsorbed onto the cell membrane of bacteria to limit the activity of bacteria. (2) $\mathrm{Cu}$ ions can penetrate the bacteria membrane into the cells and lead to leakage of the cytoplasm. (3) Cu ions can disrupt the activity of respiratory chains and disturb the process of gene replication. (4) Cu ions can lead to the damage of the central catabolic and biosynthetic pathways by oxidative stress injury.

As an essential trace element required for bone formation, Zinc $(\mathrm{Zn})$ also possesses excellent antibacterial ability. Yang et al. added both $\mathrm{Zn}$ and $\mathrm{Sr}$ ions onto the surface of magnesium alloy ZK60. The results showed that $\mathrm{Zn}$ ions showed excellent antibacterial effects on both E. coli and S. aureus [78]. Guo et al. developed a multifunctional polypyrrole/zinc oxide (Ppy/ZnO) composite coating by the cyclic voltammetry method to enhance the corrosion resistant and the antibacterial ability of Mg alloy. The composite coating showed remarkable antibacterial ability of $96.5 \% \pm 2.6 \%$ against $E$. coli [79]. The exact mechanisms for the inhibitory effects of $\mathrm{Zn}$ on the microorganisms remain unclear. The possible antibacterial ways of $\mathrm{Zn}$ ions are as follows: (1) membrane damage caused by the attack of $\mathrm{Zn}$ ions, leading to the leakage of intracellular constituents [80,81], (2) Zn ions can inhibit bacterial growth by producing a large amount of bactericidal reactive oxygen species (ROS), and (3) $\mathrm{Zn}$ ions can bind to bacterial DNA and, thus, inhibit its replication [82-84].

\subsubsection{Antibacterial Activated Copolymers}

Although many efforts have been taken to improve the corrosion resistance and the antibacterial properties of magnesium, however, adding inorganic ingredients will enhance the corrosion rate of the coatings due to the generation of galvanic corrosion. Besides this, the degradation products of the traditional antibacterial agents have potential toxicity to the surrounding tissues. Therefore, alternative antibacterial approaches based on bacteria-repellent mechanisms caught the attention of researchers. Many antibacterial surfaces such as polyethyleneglycol (PEG) [85], a natural DNase enzyme [86], zwitterion [87], and borneol [88] have been developed for biomedical and antibacterial applications. Wang et al. developed a novel biodegradable and antibacterial polyurethane coating for biomedical magnesium rods by the dip-coating method [89]. The incorporation of PEG chains and zwitterions into polyurethanes was demonstrated to endow the polymers with antibacterial performances as hydration 
barriers $[86,88]$. Sun et al. introduced a colloidal copolymer coating on magnesium, which was composed of isobornyl acrylate-co-dimethylaminoethyl methacrylate (ISA-co-DMA) fabricated by the method of electrophoretic deposition and found definite effects on cytocompatibility, antibacterial performance, and corrosion resistance in vitro and in vivo [90]. The antibacterial ingredient in their study was ISA, a well-known derivative product of natural borneol with excellent anti-inflammatory analgesic effects [91]. Bertuola et al. fabricated a multifunctional layer that was obtained by the electro-polymerization of thymol (TOH), a component of oreganum and thyme essential oils to inhibit bacterial adhesion and enhance the efficacy of antibiotic treatments [92]. Antibiotic treatment efficiency against sessile bacteria attached on AZ31 and poly TOH-AZ31 was also detected in their study.

\subsubsection{Composite Polymer Coatings Based on Plasma Electrolytic Oxidation}

Plasma electrolytic oxidation (PEO), also called micro-arc oxidation (MAO), is a common method to fabricate porous ceramic coatings on magnesium-based materials with high adhesion strengths to the substrate [93-95]. Besides improving the corrosion resistance of magnesium alloys, PEO coatings can provide excellent bonding strength and biological properties. Chen et al. evaluated the antibacterial property of a copper-containing micro-arc oxidation coating on a Mg-2Zn- $1 \mathrm{Gd}-0.5 \mathrm{Zr}$ alloy and found that the antibacterial rate of the coating against Staphylococcus aureus was up to more than 99\% [96]. In our previous study, a series of composite coatings with different amounts of $\mathrm{CuO}$ particles $(3,5$, and $7 \mathrm{wt} . \%$ ) were fabricated on pure magnesium through plasma electrolytic oxidation to investigate the in vitro biocompatibility and the antibacterial abilities against Porphyromonas gingivalis (P. gingivalis). The results of the research revealed that adding proper amounts of $\mathrm{CuO}$ into PEO coatings could significantly improve the antibacterial abilities of the PEO coatings. At the time of $72 \mathrm{~h}$, the antibacterial rates of PEO-5Cu and PEO-7Cu reached up to 100\% [40].

However, as shown in Figure 3, some micropores will inevitably generate during the PEO fabricate process. Corrosive fluids can easily permeate into the inner sites of the PEO coating, and the substrate magnesium will be exposed to the corrosive fluids in a short period. The PEO coatings can only protect the magnesium and improve its corrosion resistance at the initial corrosion process. To solve the problem, biodegradable polymers are introduced into the PEO coatings to seal the micropores generated by micro-arc oxidation. In the study of Tian et al. [97], a polycaprolactone (PCL) layer was prepared to seal the PEO coating to form a PEO/PCL composite coating on AZ31, followed by a further surface functionalization with polydopamine (PD). PD greatly enhanced the bioactivity of the PEO/PCL coating and introduced a large amount of hydroxyapatite (HA) formed on the surface of the PEO/PCL/PD coating. To further enhance the antibacterial activity of the composite coating, polyhexamethylene biguanidine (PHMB) was fabricated onto the coating surface via the assistance of polydopamine. The multifunctional coating of $\mathrm{PEO} / \mathrm{PCL} / \mathrm{PD} / \mathrm{PHMB}$ was demonstrated to have good corrosion resistance, satisfying biocompatibility with bioactivity and excellent antibacterial ability.

\subsection{CaP-Based Antibacterial Functionalized Coatings}

Calcium phosphates $(\mathrm{CaP})$ have long been used as protective coatings with satisfying biocompatibility $[98,99]$. Biologically, CaP belong to the orthophosphate group and have been demonstrated to naturally occur in several biological structures, such as teeth and bone. Furthermore, synthetic hydroxyapatite has revealed similar properties with the naturally occurring $\mathrm{CaP}$ of the inorganic component of the bone. CaP coatings have been demonstrated to have the ability of enhancing the biocompatibility of metallic implants and increasing osteogenesis at the site of implantation $[100,101]$. Consequently, $\mathrm{CaP}$ films have been widely studied as a modified membrane layer to increase the corrosion resistance of $\mathrm{Mg}$ alloys. Tan et al. fabricated a calcium phosphate/tetracycline (CaP/TC) composite coating on magnesium and found that, besides a provided optical antibacterial ability for the CaP coating, TC additives made the CaP coating more compact and uniform [102]. 

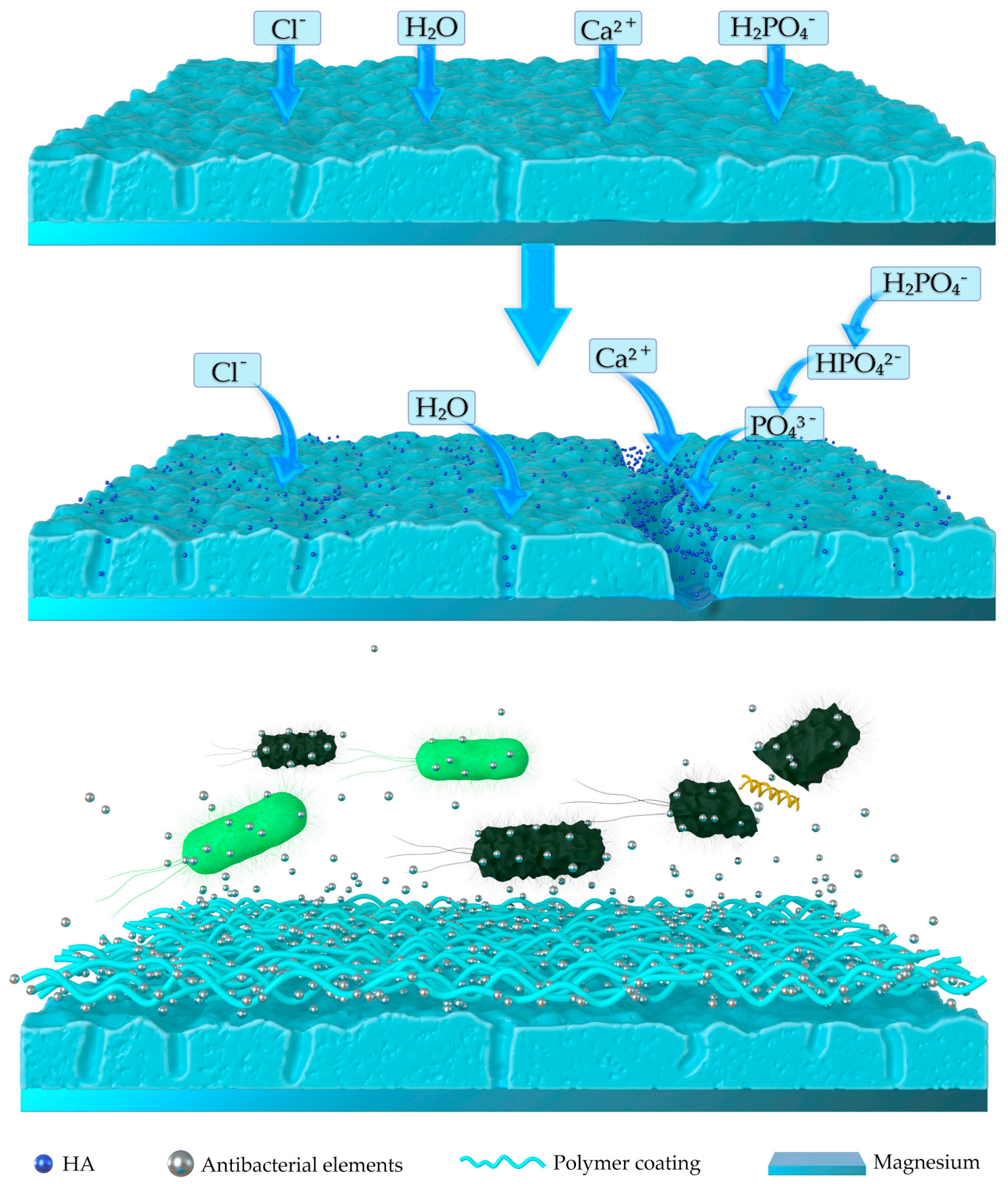

Figure 3. Schematic on the corrosion process of the plasma electrolytic oxidation (PEO) coating and PEO-based polymer coating.

As the naturally occurring mineral form of calcium apatites, hydroxyapatite $\left(\mathrm{HA}, \mathrm{Ca}_{10}\left(\mathrm{PO}_{4}\right)_{6}(\mathrm{OH})_{2}\right)$ is the major mineral component of bones and teeth. HA possesses good biocompatibility and has been used to induce and promote the formation of new bone for its favorable osteoconductivity and osteoinductivity [103-107]. Many efforts had been taken to combine HA with antibacterial elements. The typical formation processes of HA for antibacterial preparation are shown in Table 1. 
Table 1. Fabrication of hydroxyapatite (HA)-based coatings by biomimetic mineralization.

\begin{tabular}{|c|c|c|c|c|c|c|}
\hline & Coatings & Substrate & Solution & $\begin{array}{l}\text { Immersion } \\
\text { Time }\end{array}$ & Temperature & Ref. \\
\hline 2015 & $\begin{array}{l}\text { HA-PSI } 10 \\
\text { coating }\end{array}$ & AZ91 & $\begin{array}{c}7 \mathrm{mM} \mathrm{Ca}\left(\mathrm{NO}_{3}\right)_{2}, 4.2 \mathrm{mM} \\
\mathrm{NaH}_{2} \mathrm{PO}_{4} \text { and } 1 \mathrm{mM} \\
\mathrm{NaHCO}_{3}\end{array}$ & $24 \mathrm{~h}$ & $\begin{array}{c}\text { Not } \\
\text { mentioned }\end{array}$ & [32] \\
\hline 2016 & Ag-FHA coating & $\begin{array}{l}\text { High purity } \\
\operatorname{Mg}(99.98 \%)\end{array}$ & $\begin{array}{c}0.042 \mathrm{M} \mathrm{Ca}\left(\mathrm{NO}_{3}\right)_{4} \cdot 4 \mathrm{H}_{2} \mathrm{O} \\
0.1 \mathrm{M} \mathrm{NaNO}_{3}, 0.025 \mathrm{M} \\
\mathrm{NH}_{4} \mathrm{H}_{2} \mathrm{PO}_{4}, 6 \text { vol.\% } \\
\mathrm{H}_{2} \mathrm{O}_{2} \text { and } 1 \times 10^{-3} \mathrm{M} \mathrm{NaF}\end{array}$ & $2 \mathrm{~h}$ & 60 & {$[31]$} \\
\hline 2016 & $\begin{array}{l}\text { Zn-doped } \\
\text { nanowhisker } \\
\text { HA coatings }\end{array}$ & ZK60 & $\begin{array}{c}\mathrm{Ca}\left(\mathrm{NO}_{3}\right)_{2} \cdot 4 \mathrm{H}_{2} \mathrm{O}(0.05 \mathrm{M}) \\
\text { and } \mathrm{NaH}_{2} \mathrm{PO}_{4} \cdot 2 \mathrm{H}_{2} \mathrm{O} \\
(0.03 \mathrm{M})\end{array}$ & $2 \mathrm{~h}$ & 140 & [17] \\
\hline 2017 & $\begin{array}{l}\text { HA/PFLX } \\
\text { coating }\end{array}$ & AZ91 & $\begin{array}{c}0.05 \mathrm{M}_{\mathrm{EDTA}}-\mathrm{Na}_{2} \\
\mathrm{Ca}\left(\mathrm{NO}_{3}\right)_{2}, \mathrm{~K}_{2} \mathrm{HPO}_{4}\end{array}$ & $6 \mathrm{~h}$ & 94 & [108] \\
\hline
\end{tabular}

PSI 10 (RRWPWWPWRR-NH2), PFLX (pefloxacin), Ag-FHA (silver-fluoridated hydroxyapatite), Zn (zinc), and Mg (magnesium).

As the major mineral constituent of the bone matrix, HA is one of the most commonly used drug-loading coatings on magnesium alloys. The hydroxyapatite (HA)/pefloxacin (PFLX) drug-eluting layer on AZ91 was fabricated by Bai et al. the HA coating was prepared by biomimetic mineralization, followed by dipping in 1-mg/mL, 10-mg/mL, and 100-mg/mL PFLX aqueous solutions [108]. Results showed that a proper concentration $(10 \mathrm{mg} / \mathrm{mL})$ of PFLX would enhance the corrosion resistance of the HA coating. However, with the increase of PFLX, the acidity of PFLX would destroy the integrity of the HA coating. The antibacterial ability against Escherichia coli (E. coli BL21) of the HA/PFLX coating was also demonstrated in their study.

HA can also incorporate with antibacterial metal ions. Zhao et al. added silver into FHA coatings to fabricated antibacterial functional coatings on pure $\mathrm{Mg}$ with satisfying corrosion resistance [31]. Wang et al. proposed a mussel-inspired nano-multilayered coating with a chitosan-Cap ${ }^{\circledR} \mathrm{PDA}$-chitosan-Ag ${ }^{\circledR} \mathrm{PDA}$ periodic unit on AZ31 magnesium alloy to combine the advantages of the antibacterial activity of silver nanoparticles, the excellent bioactivity and osteoconductivity of biomimetic Cap nanoparticles, the strong adhesion of PDA (polydopamine), and the biocompatibility of chitosan [109]. In the study of Zhou et al., $\mathrm{Zn}$ is doped into a hydroxyapatite coating on the surface of ZK60 magnesium alloys using the one-pot hydrothermal method to obtain a corrosion-resistant implant with the abilities of osteogenic differentiation and bacterial inhibition [17].

Antimicrobial peptides (AMPs) are well-known components of the innate immunity, which are produced by all species of life [110]. These peptides are broad-spectrum-resistant to both Gram-positive and Gram-negative bacteria [111]. Compared to conventional antibiotics, AMPs are insusceptible during the antibacterial process and, thus, have reliable antibacterial properties, especially for the antibiotic-resistant bacteria. Due to their cationic property, the AMPs selectively interact with the bacterial cells rather than the mammalian cells to make them highly antimicrobial with a low toxicity for host cells [112]. At present, there are few studies on the surface modification of Mg alloys using AMPs. Tian et al. [32] developed a magnesium alloy surface with a HA coating for delivering AMPs. The biomimetic method was taken to fabricate the HA-AMP coating, and the AMP of PSI 10 (RRWPWWPWRR-NH2) was loaded in the HA coating for $11.16 \pm 1.99 \mu \mathrm{g} / \mathrm{cm}^{2}$. In vitro and in vivo studies were taken to demonstrate the biocompatibility, antibacterial ability, and osteogenesis effects of the HA-AMP coating. It has also been demonstrated that HA coatings have high drug-loading efficiency for the antimicrobial peptides and controllable slow release rates. 


\section{Overall Performances of Antibacterial-Functionalized Coatings on Magnesium}

\subsection{An Overview on Antibacterial-Functionalized Coatings}

Table 2 provides an overview of different antibacterial coatings on magnesium and its alloys. It can be seen from the table that multifunctional coatings with the properties of good corrosion resistance and excellent antibacterial ability are combination with a verity of materials. Biodegradable polymers with good biocompatibility such as polydopamine (PD) [24], polycaprolactone (PCL) [67,97], poly (D, L-lactic acid) $[63,64]$ are the most frequently used coating materials. Moreover, many studies were concentrated on dipping [24,53,102,106], layer-by-layer (LbL) assembly [58], and electrophoretic deposition [31,109] to combine the properties of different polymers. For the substrates, AZ31 was the most frequently used base material, followed by AZ91 and pure magnesium. Dipping was the most frequently used method to fabricate antibacterial coatings; electrochemical depositions and PEO were also commonly adopted by researchers. The thickness of the coatings was $4-15 \mu \mathrm{m}$ and $100-200 \mathrm{~nm}$ for the nanoparticle coatings.

Table 2. An overview on antibacterial-functionalized coatings.

\begin{tabular}{|c|c|c|c|c|c|c|c|}
\hline Year & Coating Systems & $\begin{array}{l}\text { Coating Base } \\
\text { Material }\end{array}$ & $\begin{array}{l}\text { Antibacterial } \\
\text { Ingredient }\end{array}$ & Substrate & Methods & $\begin{array}{l}\text { Coating } \\
\text { Thickness }\end{array}$ & Ref. \\
\hline 2015 & Sirolimus-PGA & PGA & Sirolimus & AZ31 & Dipping & NM & {$[53]$} \\
\hline 2015 & HA-PSI 10 coating & HA & $\begin{array}{l}\text { Antimicrobial } \\
\text { peptides } \\
\text { (AMPs) }\end{array}$ & AZ91 & $\begin{array}{l}\text { biomimetic } \\
\text { mineralization }\end{array}$ & NM & {$[32]$} \\
\hline 2016 & $\begin{array}{l}\mathrm{CaP} / \mathrm{TC} \text { composite } \\
\text { coating }\end{array}$ & $\begin{array}{c}\text { calcium phosphate } \\
(\mathrm{CaP})\end{array}$ & $\begin{array}{l}\text { Tetracycline } \\
\text { (TC) }\end{array}$ & AZ91D & Dipping & $\sim 8.0 \mu \mathrm{m}$ & [102] \\
\hline 2016 & Ag-FHA coating & $\begin{array}{c}\text { Fluoridated } \\
\text { hydroxyapatite } \\
\text { (FHA) }\end{array}$ & $\mathrm{Ag}$ & magnesium & $\begin{array}{l}\text { electrochemical } \\
\text { deposition }\end{array}$ & NM & {$[31]$} \\
\hline 2016 & ISA-co-DMA/TA & DMA/TA & $\begin{array}{l}\text { isobornyl } \\
\text { acrylate } \\
\text { (ISA) }\end{array}$ & pure $\mathrm{Mg}$ & $\begin{array}{l}\text { electrophoretic } \\
\text { deposition }\end{array}$ & $80-125 \mathrm{~nm}$ & {$[90]$} \\
\hline 2016 & $\begin{array}{l}\text { PEO/PCL/PHMB } \\
\text { composite coating }\end{array}$ & $\begin{array}{l}\text { PEO/PCL composite } \\
\text { coating }\end{array}$ & PHMB & AZ31 & PEO & NM & [97] \\
\hline 2017 & HA/PFLX & HA & $\begin{array}{l}\text { pefloxacin } \\
\text { (PFLX) }\end{array}$ & AZ91 & $\begin{array}{l}\text { hydrothermal } \\
\text { and dip }\end{array}$ & NM & [108] \\
\hline 2017 & $\begin{array}{l}\text { chitosan-CAp@PDA- } \\
\text { chitosan-Ag@PDA }\end{array}$ & chitosan-CAp@PDA & $\mathrm{Ag}$ & AZ31 & layer by layer & $100 \mathrm{~nm}$ & [109] \\
\hline 2017 & $\begin{array}{c}\text { Cu-releasing } \\
\text { BG/PCL Coating }\end{array}$ & $\begin{array}{l}\text { polycaprolactone } \\
\text { (PCL) }\end{array}$ & $\mathrm{Cu}-\mathrm{BGNs}$ & pure $\mathrm{Mg}$ & Spin coating & $8 \pm 2 \mu \mathrm{m}$ & [67] \\
\hline 2017 & $\begin{array}{l}\text { PDLLA/RAPA } \\
\text { coating }\end{array}$ & PDLLA & rapamycin & $\mathrm{Mg}-\mathrm{Nd}-\mathrm{Zn}-\mathrm{Zr}$ & $\begin{array}{c}\text { ultrasonic } \\
\text { spray-coating }\end{array}$ & 4-6 um & {$[64]$} \\
\hline 2017 & $\begin{array}{l}\text { SRL loaded } \\
\text { PDLLA-PCL } \\
\text { double layer }\end{array}$ & $\begin{array}{l}\text { PDLLA-PCL } \\
\text { double layer }\end{array}$ & $\begin{array}{l}\text { sirolimus } \\
\text { SRL }\end{array}$ & AZ 31 & $\begin{array}{l}\text { ExactaCoat } \\
\text { Ultrasonic } \\
\text { Spraying }\end{array}$ & NM & [63] \\
\hline 2018 & AgNPs-PMTMS & PMTMS & $\begin{array}{c}\text { silver } \\
\text { nanoparticles } \\
\text { (AgNPs) }\end{array}$ & AZ 31 & $\begin{array}{l}\text { layer-by-layer } \\
\text { (LbL) assembly }\end{array}$ & NM & [58] \\
\hline 2018 & $\begin{array}{l}\text { polymeric layer } \\
(\text { poly TOH })\end{array}$ & Poly $\mathrm{TOH}$ & $\begin{array}{l}\text { thymol } \\
\text { (TOH) }\end{array}$ & AZ31 & $\begin{array}{l}\text { potentiodynamic } \\
\text { electrochemical }\end{array}$ & NM & [92] \\
\hline 2019 & $\begin{array}{l}\text { Ag and Au NPs } \\
\text { enriched PD-HF } \\
\text { coating }\end{array}$ & $\begin{array}{l}\text { Polydopamine- } \\
\text { Hydrofluoric acid }\end{array}$ & $\begin{array}{c}\mathrm{Ag} / \mathrm{Cu} \\
\text { Nanoparticle }\end{array}$ & AZ31 & Dipping & NM & [24] \\
\hline 2019 & $\begin{array}{l}\text { Copper-containing } \\
\text { MAO coating }\end{array}$ & $\begin{array}{c}\text { Nano } \\
\text { hydroxyapatite }\end{array}$ & Copper & $\mathrm{Mg}-2 \mathrm{Zn}-1 \mathrm{Gd}-0.5 \mathrm{Zr}$ & $\begin{array}{l}\text { Micro-arc } \\
\text { oxidation }\end{array}$ & $8-11 \mu \mathrm{m}$ & [96] \\
\hline 2019 & GPU-ZPU & PU & $\begin{array}{l}\text { PEG and } \\
\text { zwitterions }\end{array}$ & $\mathrm{Mg}$ & Dipping & $\sim 4-15 \mu \mathrm{m}$ & [106] \\
\hline
\end{tabular}

PD: polydopamine, HF: hydrofluoric acid, FHA: fluoridated hydroxyapatite, PHMB: polyhexamethylene biguanidine, CAp: carbonated apatite, PCL: polycaprolactone, $\mathrm{Cu}$-BGNs: copper $(\mathrm{Cu})$-containing bioactive glass nanoparticles, PMTMS: polymethyltrimethoxysilane, PGA: polyglutamic acid, PU: polyurethanes, PEG: polyethyleneglycol, AMPS: antimicrobial peptides, and NM: not mentioned.

\subsection{Antibacterial Abilities of Different Antibacterial Coatings on Magnesium}

Staphylococcus aureus has been recognized as an important pathogen for more than 100 years, which represents by far the most common pathogen found in surgical wounds. Table 3 provides an overview of the antibacterial abilities in the latest studies on magnesium-based antibacterial coatings. 
For the antibacterial studies, most antibacterial coatings showed effective antibacterial properties on $\mathrm{G}^{+}$Staphylococcus aureus or $\mathrm{G}^{-}$Escherichia coli. Some of these studies evaluate both of them. Research studies on magnesium-based antibacterial coatings were concentrated on aerobic bacteria. However, articles about the antibacterial abilities of magnesium coatings on anaerobic bacteria were rare. Table 4 shows the distribution of bacteria revealed in these studies. Table 5 exhibits the evaluation methods of these research studies in detail. For the research methods, an immersion test was the most frequently used method. The antibacterial abilities of biomedical materials are time-dependent and concentration-dependent. Immersion times differ from different bacteria reproductive cycles, antibacterial ingredients, antibacterial ingredient concentrations, and the releasing rates. A novel gentamicin-loaded HA coating was introduced by Ji et al. $[19,21]$ by the Layer-by-Layer (LbL) assemble method. The antibacterial coating possessed effective antibacterial properties due to the local high GS concentration. The antibacterial activity of the samples was tested against Gram-positive Staphylococcus aureus (S. aureus, ATCC 6538) by the plate-counting method. The colony-forming units (CFUs) of S. aureus increased in the following order: (PAA/GS)20/PAA-HAp coating ( $1 \pm 1 \mathrm{CFU})<\mathrm{AZ31}$ substrate $(538 \pm 16 \mathrm{CFU})<$ pure HAp coating $(1659 \pm 24 \mathrm{CFU})<$ blank group $(1913 \pm 30 \mathrm{CFU})$. Besides the immersion test, SEM was the most frequently used method, followed by live/dead fluorescent staining. In vivo studies on antibacterial effects were rare. Antibacterial mechanisms, molecular biological changes during the antibacterial progress, and more in vivo studies should be taken for further research on the antibacterial evaluation of magnesium-based antibacterial coatings.

Table 3. Antibacterial results of different antibacterial-functionalized coatings on magnesium.

\begin{tabular}{|c|c|c|c|c|}
\hline Year & Coating Systems & $\begin{array}{c}\text { Antibacterial Ability on } \\
\text { G+ Bacteria }\end{array}$ & $\begin{array}{l}\text { Antibacterial } \\
\text { Ability on } \\
\text { G- Bacteria }\end{array}$ & Ref. \\
\hline 2015 & HA-PSI 10 coating & $\begin{array}{c}\text { Staphylococcus aureus } \\
\text { ATCC } 25923\end{array}$ & - & [32] \\
\hline 2016 & Ag-FHA coating & $\begin{array}{c}\text { Methicillin resistant } \\
\text { Staphylococcus aureus } \\
\text { ATCC } 43300\end{array}$ & - & [31] \\
\hline 2016 & $\begin{array}{l}\mathrm{CaP} / \mathrm{TC} \text { composite } \\
\text { coating }\end{array}$ & $\begin{array}{c}\text { Staphylococcus aureus } \\
\text { ATCC } 25923\end{array}$ & - & [102] \\
\hline 2016 & ISA-co-DMA/TA & $\begin{array}{c}\text { Staphylococcus aureus } \\
\text { ATCC } 6538\end{array}$ & $\begin{array}{l}\text { Escherichia coli } \\
\text { ATCC } 8739\end{array}$ & [73] \\
\hline 2016 & $\begin{array}{l}\mathrm{PEO} / \mathrm{PCL} / \mathrm{PHMB} \\
\text { composite coating }\end{array}$ & $\begin{array}{c}\text { Staphylococcus aureus } \\
\text { ATCC } 25923\end{array}$ & $\begin{array}{l}\text { Escherichia coli } \\
\text { ATCC } 52922\end{array}$ & [97] \\
\hline 2017 & HA/PFLX & - & $\begin{array}{l}\text { Escherichia coli } \\
\text { (E. coli BL21). }\end{array}$ & [108] \\
\hline 2017 & $\begin{array}{l}\text { chitosan-Cap@PDA- } \\
\text { chitosan-Ag@PDA }\end{array}$ & $\begin{array}{c}\text { Staphylococcus aureus } \\
\text { ATCC } 29213\end{array}$ & $\begin{array}{l}\text { Escherichia coli } \\
\text { ATCC } 52922\end{array}$ & [109] \\
\hline 2017 & $\begin{array}{l}\text { Cu-releasing BG/PCL } \\
\text { Coating }\end{array}$ & Staphylococcus carnosus & Escherichia coli & [67] \\
\hline 2018 & AgNPs-PMTMS & Staphylococcus aureus & - & [58] \\
\hline 2018 & $\begin{array}{l}\text { polymeric layer } \\
\text { (poly } \mathrm{TOH})\end{array}$ & $\begin{array}{c}\text { Staphylococcus aureus } \\
\text { ATCC } 25923\end{array}$ & - & [92] \\
\hline 2019 & $\begin{array}{c}\text { Ag and Au NP-enriched } \\
\text { PD-HF coating }\end{array}$ & $\begin{array}{c}\text { Staphylococcus aureus } \\
\text { ATCC } 29231\end{array}$ & $\begin{array}{l}\text { Escherichia coli } \\
\text { ATCC } 52922\end{array}$ & [24] \\
\hline 2019 & $\begin{array}{l}\text { Copper-containing } \\
\text { MAO coating }\end{array}$ & $\begin{array}{c}\text { Staphylococcus aureus } \\
\text { ATCC } 25923\end{array}$ & - & [79] \\
\hline 2019 & GPU-ZPU & - & $\begin{array}{l}\text { E. coli and } \\
\text { P. aeruginosa }\end{array}$ & [106] \\
\hline
\end{tabular}


Table 4. Bacteria distributions in the antibacterial tests.

\begin{tabular}{|c|c|c|c|c|}
\hline Bacteria Assay & G+/G- & $\begin{array}{c}\text { Anaerobic } \\
\text { Bacteria }\end{array}$ & Aerobic Bacteria & Ref. \\
\hline $\begin{array}{c}\text { Staphylococcus aureus } \\
\text { ATCC } 29231\end{array}$ & G+ & & + & {$[24,32,79,102]$} \\
\hline $\begin{array}{c}\text { Staphylococcus aureus } \\
\text { ATCC } 25923\end{array}$ & G+ & & + & [75] \\
\hline $\begin{array}{c}\text { Staphylococcus aureus } \\
\text { ATCC } 6538\end{array}$ & G+ & & + & [81] \\
\hline $\begin{array}{c}\text { Staphylococcus aureus } \\
\text { ATCC } 29213\end{array}$ & G+ & & + & [109] \\
\hline $\begin{array}{l}\text { Methicillin-resistant } \\
\text { Staphylococcus aureus } \\
\text { (ATCC 43300) }\end{array}$ & G+ & & + & [109] \\
\hline Escherichia coli ATCC 8739 & G- & & + & [90] \\
\hline $\begin{array}{l}\text { Escherichia coli } \\
\text { (E. coli BL21). }\end{array}$ & G- & & + & [108] \\
\hline P. aeruginosa & G- & & + & [106] \\
\hline P. gingivalis & G- & + & & [36] \\
\hline
\end{tabular}

Table 5. Methods taken in the antibacterial tests. CFU: colony-forming unit.

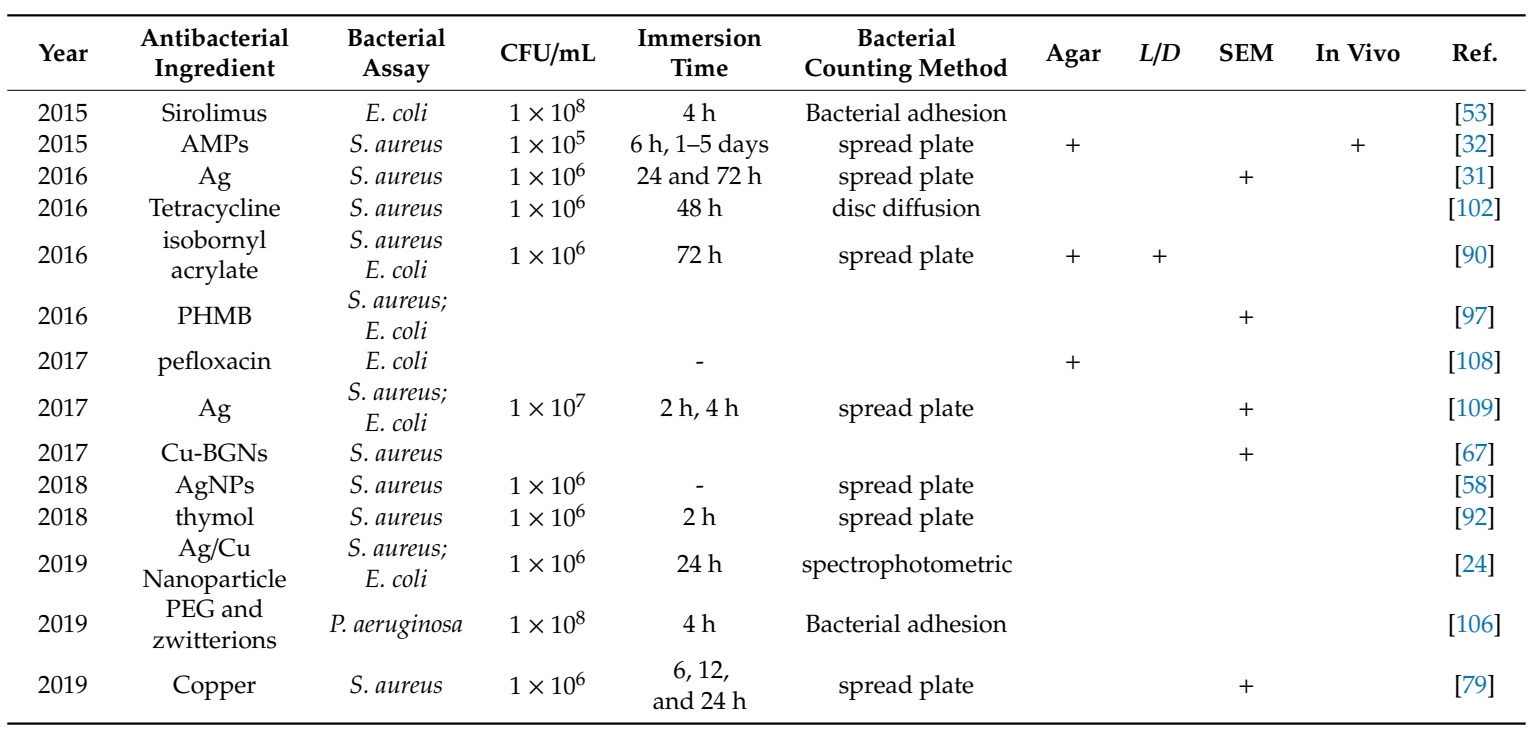

\subsection{In Vitro Cytocompatibility}

Typical studies on in vitro cytocompatibility are shown in Table 6 . In cell studies, the cytocompatibility and positive effects of antibacterial coatings on cell proliferation were frequently shown for bone-linked cells such as murine osteoblast-like cell line MC3T3-E1 [18-20,24,27] and human osteoblast cell line MG-63 $[67,96]$. Besides proliferation, cell adhesion and osteoblast differentiation were also evaluated in most of the studies. Direct and indirect cell proliferation tests were taken in the study of Yang's to evaluate the cytotoxicity of $\mathrm{Cu}-\mathrm{BGN}$ coatings [67]. The results showed that, compared with pure magnesium, the $\mathrm{Cu}-\mathrm{BGN}$ coating greatly improves the proliferation and osteoblast differentiation of MG-63 cells. In the study of Zhou's, the Zn-doped nanowhisker coating promoted the adhesion and differentiation of rat bone marrow mesenchymal stem cells at appropriate $\mathrm{Zn}$ concentrations [17]. 
Table 6. An overview on the in vitro cytocompatibilit yof antibacterial-functionalized coatings on magnesium and its alloys.

\begin{tabular}{|c|c|c|c|c|c|c|c|c|}
\hline Year & Coating & Substrates & Cell Type & $\begin{array}{c}\text { Cell } \\
\text { Proliferation }\end{array}$ & $\begin{array}{c}\text { Osteoblast } \\
\text { Differentiation }\end{array}$ & $\begin{array}{c}\text { Cell } \\
\text { Adhesion }\end{array}$ & In Vivo & Refs. \\
\hline 2015 & AMP-HA & AZ91 & rBMMSCs & improved & improved & NM & + & {$[32]$} \\
\hline 2016 & $\begin{array}{l}\text { MAO/PLLA } \\
\text { coating }\end{array}$ & Mg-1Li-1Ca alloy & МС3Т3-E1 & improved & improved & improved & & [27] \\
\hline 2016 & $\begin{array}{l}\text { Ag-FHA } \\
\text { coating }\end{array}$ & Pure magnesium & MC3T3-E1 & improved & NM & improved & & {$[31]$} \\
\hline 2016 & $\begin{array}{c}\text { (ISA-co- } \\
\text { DMA)/TA }\end{array}$ & Magnesium & L929 & improved & improved & improved & & {$[90]$} \\
\hline 2017 & $\begin{array}{l}\text { Cu-releasing } \\
\text { BG/ PCL } \\
\text { coating }\end{array}$ & Magnesium & MG63 & improved & improved & NM & & [67] \\
\hline 2019 & $\begin{array}{l}(\mathrm{PAA} / \mathrm{GS})_{20} / \\
\text { PAA-Hap } \\
\text { coating }\end{array}$ & AZ31 & MC3T3-E1 & $\begin{array}{l}\text { Slightly } \\
\text { reduced }\end{array}$ & improved & improved & & [19] \\
\hline 2019 & $\begin{array}{l}\text { GONPs/PT } \\
\text { Zn-doped }\end{array}$ & AZ91E & HGaEpC cell & improved & NM & NM & & {$[28]$} \\
\hline 2019 & $\begin{array}{l}\text { nanowhisker } \\
\text { HA coatings } \\
\text { Zinc-loaded }\end{array}$ & ZK60 & BMSCs & improved & improved & improved & & [17] \\
\hline 2019 & $\begin{array}{l}\text { montmorillonite } \\
\text { coatings }\end{array}$ & AZ31 & МС3Т3-E1 & improved & NM & NM & & {$[18]$} \\
\hline 2019 & $\begin{array}{c}\text { UMAO- } \\
\text { phytic acid-Cu } \\
\mathrm{Ag} / \mathrm{Au}\end{array}$ & Pure magnesium & MC3T3-E1 & improved & improved & improved & + & [20] \\
\hline 2019 & $\begin{array}{l}\text { Nanoparticle } \\
\text { Coating }\end{array}$ & AZ31 & MC3T3-E1 & improved & NM & improved & & [24] \\
\hline 2019 & $\begin{array}{l}\text { Copper-bearing } \\
\text { MAO coating }\end{array}$ & $\begin{array}{c}\mathrm{Mg}-2 \mathrm{Zn} \\
-1 \mathrm{Gd}-0.5 \mathrm{Zr}\end{array}$ & MG63 & improved & NM & NM & & [79] \\
\hline
\end{tabular}

rBMMSCs: rat bone marrow mesenchymal stem cells, (ISA-co-DMA)/TA: (isobornyl acrylate-co dimethylaminoethyl methacrylate)/tannic acid, GONPs/PT: graphene oxide nanoparticles/polythreonine and NM: not mentioned.

\subsection{Corrosion Resistance of Different Antibacterial Coatings on Magnesium}

As an electronegative engineering metal with an electrochemical potential of $-2.3 \mathrm{~V}$ versus a standard hydrogen electrode, magnesium is highly susceptible to corrosion in most aqueous environments, including human body fluids. The corrosion products of magnesium alloys are generated in the process of degradation after being implanted into the human body. The degradation of magnesium alloys will give rise to metal ions; chemical reaction products (such as the oxides, hydroxides, phosphates, carbonates, etc.); and hydrogen gas. The most common product of Mg alloys is $\mathrm{Mg}(\mathrm{OH})_{2}$, which displays moderate solubility and is found to slowly dissolve or react with chloride ions to become soluble $\mathrm{MgCl}_{2}$ [113]. Other kinds of reaction products, such as $\mathrm{MgCO}_{3}, \mathrm{Mg}_{3}\left(\mathrm{PO}_{4}\right)_{2}$, $\mathrm{Zn}(\mathrm{OH})_{2}, \mathrm{Zn}_{3}\left(\mathrm{PO}_{4}\right)_{2}$, and $\mathrm{Ca}_{3}\left(\mathrm{PO}_{4}\right)_{2}$, exhibit much lower solubility in water and may be difficult to clear from the implantation site. However, these metal salts may show good biocompatibility in the human body, especially in bone tissues. For example, $\mathrm{MgCO}_{3}$ is used as a component of bio-glass, $\mathrm{Mg}_{3}\left(\mathrm{PO}_{4}\right)_{2}$ and $\mathrm{Ca}_{3}\left(\mathrm{PO}_{4}\right)_{2}$ are used for bone cements, and $\mathrm{Zn}_{3}\left(\mathrm{PO}_{4}\right)_{2}$ is used as a dietary supplement [114]. Additionally, hydrogen gas $\left(\mathrm{H}_{2}\right)$ evolution during magnesium corrosion can create subcutaneous gas bubbles [115,116]. This phenomenon was also detected in a clinical study [33]. However, it should be noted that previous in vivo studies have shown that the hydrogen-forming gas pockets would only be detected in the first week post-surgery and gradually disappear over a period of two to three weeks post-surgery [117]. Thus, hydrogen evolution may not significantly interfere with the healing process. It was reported that the gas cavities due to hydrogen evolution were not observed for most of the coated Mg-based alloys, which show a slower initial degradation rate compared to the bare alloys [118].

Corrosion resistance of the functional coatings is one of the most important properties that affects the clinical application of magnesium alloys. An ideal orthopedic material should provide sufficient support to promote the healing of the bone in the initial period of implantation and then gradually degrade with a controllable degradation rate in three to six months. An overview of long-time immersion 
tests is shown in Table 7. It can be seen from the table that the immersion time for corrosion-resistant tests was mainly 7-28 days. The most frequently used electrolytes for corrosion resistance tests was SBF, followed by Hank's solution and the cell culture medium. The corrosion properties of different antibacterial coatings are exhibited in Table 8. Considering different electrolytes and the immersion ratio, the corrosion resistance between different antibacterial coatings was incomparable. However, it can be seen in the table that the corrosion resistance of all the coated samples is much better than that of the substrate magnesium alloys.

Table 7. An overview on long-time immersion tests.

\begin{tabular}{|c|c|c|c|c|c|c|c|}
\hline Year & Coating Systems & Substrates & Electrolyte & pH Value & Ratio $\left(\mathrm{cm}^{2} / \mathrm{mL}\right)$ & $\begin{array}{l}\text { Immersion } \\
\text { Time }\end{array}$ & Refs. \\
\hline 2015 & Sirolimus-PGA & AZ31 & HBSS & NM & 0.128 & 35 days & [53] \\
\hline 2016 & $\begin{array}{l}\mathrm{CaP} / \mathrm{TC} \text { composite } \\
\text { coating }\end{array}$ & AZ91D & SBF & NM & NM & 5 days & [102] \\
\hline 2016 & ISA-co-DMA/TA & Magnesium & SBF & 7.4 & NM & 40 days & [90] \\
\hline 2016 & $\begin{array}{l}\mathrm{PEO} / \mathrm{PCL} / \mathrm{PHMB} \\
\text { composite coating }\end{array}$ & AZ31 & SBF & NM & $1: 2$ & 28 days & [97] \\
\hline 2017 & HA/PFLX & AZ91 & Hank's solution & NM & NM & NM & [108] \\
\hline 2017 & $\begin{array}{l}\text { chitosan-Cap@PDA- } \\
\text { chitosan-Ag@PDA }\end{array}$ & AZ31 & SBF & 8.3 & $1: 50$ & 14 days & [109] \\
\hline 2017 & $\begin{array}{l}\text { Cu-releasing } \\
\text { BG/PCL Coating }\end{array}$ & pure $\mathrm{Mg}$ & DMEM & NM & NM & 7 days & [67] \\
\hline 2019 & $\begin{array}{l}\mathrm{Ag} \text { and } \mathrm{Au} \text { NPs } \\
\text { enriched PD-HF } \\
\text { coating }\end{array}$ & AZ31 & SBF & 7.4 & $1: 30$ & 7 days & [24] \\
\hline 2019 & $\begin{array}{l}\text { Copper-containing } \\
\text { MAO coating }\end{array}$ & $\mathrm{Mg}-2 \mathrm{Zn}-1 \mathrm{Gd}-0.5 \mathrm{Zr}$ & Hank's solution & 7.7 & 1.25 & 14 days & [79] \\
\hline 2019 & Polyurethanes (PU) & MG & SBF & $>7.5$ & 0.0647 & 49 days & [106] \\
\hline
\end{tabular}

Table 8. An overview on corrosion resistance. CR: corrosion resistance.

\begin{tabular}{|c|c|c|c|c|c|c|c|c|c|c|}
\hline \multirow{2}{*}{ Year } & \multicolumn{3}{|c|}{$I_{\text {corr }}\left(\mu \mathrm{A} / \mathrm{cm}^{2}\right)$} & \multicolumn{3}{|c|}{$E_{\text {corr }}(\mathrm{V})$} & \multicolumn{3}{|c|}{ CR $(\mathrm{mm} / \mathrm{y})$} & \multirow{2}{*}{ Refs. } \\
\hline & Substrate & Inner & Composite & Substrate & Inner & Composite & Substrate & Inner & Composite & \\
\hline 2015 & 2.96 & NM & $\begin{array}{l}\text { PGA30:6.75/ } \\
\text { PGA50:1.63 }\end{array}$ & -1.47 & NM & $\begin{array}{c}\text { PGA30: } \\
-1.39 / \text { PGA50: } \\
-1.294\end{array}$ & $1.71 \pm 0.21$ & NM & $\begin{array}{c}\text { PGA30:1.48 } \pm \\
\text { 0.16/PGA50:1.21 } \pm 0.48\end{array}$ & {$[53]$} \\
\hline 2016 & 2100 & NM & $\begin{array}{c}\mathrm{MgCP}_{30}: \\
980 / \mathrm{MgCP}_{60}: 570\end{array}$ & -1.8 & NM & $\begin{array}{c}\mathrm{MgCP}_{30}: \\
-1.51 / \mathrm{MgCP}_{60}: \\
-1.43\end{array}$ & 24.69 & NM & $\begin{array}{c}\mathrm{MgCP}_{30}: \\
\text { 13.21/MgCP }\end{array}$ & {$[90]$} \\
\hline 2016 & 14.02 & $3.260 \times 10^{-4}$ & $1.843 \times 10^{-4}$ & -1.508 & -1.342 & -1.303 & NM & NM & NM & {$[97]$} \\
\hline 2019 & 25.137 & 3.189 & Ag:2.33/Au:2.47 & -1.48 & -1.45 & $\begin{array}{l}\text { Ag:-1.33/ } \\
\text { Au:- }-1.17\end{array}$ & 82.24 & 10.43 & Ag:7.61/Au:8.07 & {$[24]$} \\
\hline 2019 & $5.460 \pm 0.990$ & $0.273 \pm 0.051$ & $0.168 \pm 0.042$ & $-1.510 \pm 0.010$ & $-1.520 \pm 0.010$ & $-1.510 \pm 0.010$ & $0.120 \pm 0.023$ & $0.006 \pm 0.001$ & $0.004 \pm 0.001$ & [79] \\
\hline 2019 & $353.8 \pm 14.5$ & $80.38 \pm 3.7$ & $1.422 \pm 0.07$ & $-2.140 \pm 0.02$ & $-1.9176 \pm 0.02$ & $-1.7007 \pm 0.03$ & NM & NM & NM & [106] \\
\hline
\end{tabular}

NM: not mentioned.

In vitro drug-releasing tests were taken in some of the studies to evaluate the dynamic drug-releasing profiles of the coatings. A novel gentamicin-loaded HA coating was introduced by Ji et al. by the Layer-by-Layer (LbL) assemble method. The antibacterial coating displayed the desired drug release profile: burst release during the initial $24 \mathrm{~h}$ (approximately $5.2 \mu \mathrm{g} \cdot \mathrm{cm}^{-2}, 23.1 \%$ ) and subsequent long-term slow release for 15 days (almost $19.98 \mu \mathrm{g} \cdot \mathrm{cm}^{-2}, 88.78 \%$ ) [19]. In the study of Zhao et al., GS releasing tests were taken for gentamicin-loaded polyelectrolyte multilayer coatings with and without heat treatments [58]. The results showed that the drug from the coating without heat treatment exhibited a burst release (about 91.5\%) in the first $24 \mathrm{~h}$, and it took about $72 \mathrm{~h}$ to release almost all of the GS. While, for the heat treatment coating, a relatively rapid release was detected within the first $12 \mathrm{~h}$, followed by a slow and sustained release profile for approximately $288 \mathrm{~h}$. The releasing rate and the concentration of the antibiotics in the surrounding tissue should be different for a variety of clinical demands. When used as an orthopedic appliance, there would be a burst of drug-releasing in the first day after implantation, followed by slower releasing in the following two weeks. However, when magnesium is used as a cardiovascular stent, the release of antibiotics in the coatings would 
be slow and steady for more than three months. Considering the different releasing rates between in vitro tests and in vivo tests, the immersion time of the in vitro study should be shorter than that of the in vivo study.

It must be taken into account that the overall corrosion rate in vivo was generally lower than that obtained in vitro due to the variation of the physiological environment through changes in the concentrations of chloride ions, organic and inorganic components, and buffer systems, as well as flow rates, water content of tissues, and stability of the corrosion layers [38]. Walker et al. reported that pure $\mathrm{Mg}$ and $\mathrm{Mg}$ alloys demonstrated significantly higher corrosion rates in a subcutaneous environment in Lewis rats than that in the in vitro tests [119]. At present, most investigations are still done under in vitro conditions. Future research should focus on corrosion behaviors in more complex in vivo conditions. Drug-releasing control to meet the different demands of clinical treatments will be the focus of concern in the near future.

\section{Conclusions}

As a "smart" biodegradable material, magnesium is recognized as the next generation of orthopedic appliances and bioresorbable scaffolds. On the other hand, magnesium is also an "active" material with a rapid and uncontrollable corrosion rate. Considering the extremely complex biological environment in the human body and the demands of enhancing corrosion resistance, biocompatibility, osteogenesis, and antibacterial ability, composite coatings with combined properties of different materials may be promising. This review article highlights the antibacterial properties of multi-functionalized coatings on magnesium and its alloys. As the most frequently used coating materials on magnesium, various polymer coatings play different roles in biomedical functions. Antibacterial ingredients such as antibiotics, antibacterial metallic ions, and antimicrobial peptides have been adopted to enhance the antibacterial properties of the coatings. Many exciting results and revolutionary achievements have been achieved during the last decades. However, it must be taken into account that the majority of existing investigations were taken in in vitro conditions and concentrated on a single or two properties. Most of the studies proceeded to exhibit biological performances rather than explore the mechanisms. There is still a long way to go for the application of antibacterial-functionalized coatings on magnesium and its alloys. More research studies are needed for the in vivo degradation performances and antibacterial abilities of antibacterial-functionalized coatings. Controlling the degradation rate and studying different combinations of multilayer coatings are important goals that will receive increasing attention in the near future.

Author Contributions: Conceptualization, D.Z. and Q.W.; Writing-original draft preparation, D.Z., Y.L. and Z.L.; writing-review and editing, Q.W. All authors have read and agreed to the published version of the manuscript.

Funding: This research received no external funding.

Conflicts of Interest: The authors declare no conflict of interest.

\section{References}

1. Wang, Y.Y.; Normand, B.; Liao, H.L.; Zhao, G.F.; Mary, N.; Tang, J.L. SiC $\mathrm{p} /$ Al5056 Composite Coatings Applied to A Magnesium Substrate by Cold Gas Dynamic Spray Method for Corrosion Protection. Coatings 2020, 10, 325. [CrossRef]

2. Tan, L.L.; Yu, L.; Wan, P.; Yang, K. Biodegradable Materials for Bone Repairs: A Review. J. Mater. Sci. Technol. 2013, 29, 503-513. [CrossRef]

3. Witte, F.; Kaese, V.; Haferkamp, H.; Switzer, E.; Meyer-Lindenberg, A.; Wirth, C.J.; Windhagen, H. In vivo corrosion of four magnesium alloys and the associated bone response. Biomaterials 2005, 26, 3557-3563. [CrossRef]

4. Zheng, Y.F.; Gu, X.N.; Witte, F. Biodegradable metals. Mater. Sci. Eng. R Rep. 2014, 77, 1-34. [CrossRef]

5. Witte, F. The history of biodegradable magnesium implants: A review. Acta Biomater. 2010, 6, 1680-1692. [CrossRef] [PubMed] 
6. Staiger, M.P.; Pietak, A.M.; Huadmai, J.; Dias, G. Magnesium and its alloys as orthopedic biomaterials: A review. Biomaterials 2006, 27, 1728-1734. [CrossRef] [PubMed]

7. Gray-Munro, J.E.; Seguin, C.; Strong, M. Influence of surface modification on the in vitro corrosion rate of magnesium alloy AZ31. J. Biomed. Mater. Res. Part. A 2009, 91, 221-230. [CrossRef]

8. Zhang, W.; Tan, L.L.; Ni, D.R.; Chen, J.X.; Zhao, Y.C.; Liu, L.; Shuai, C.J.; Yang, K.; Atrens, A.; Zhao, M.C. Effect of grain refinement and crystallographic texture produced by friction stir processing on the biodegradation behavior of a Mg-Nd-Zn alloy. J. Mater. Sci. Technol. 2019, 35, 777-783. [CrossRef]

9. Li, L.Y.; Cui, L.Y.; Zeng, R.C.; Li, S.Q.; Chen, X.B.; Zheng, Y.F.; Kannand, M.B. Advances in Functionalized Polymer Coatings on Biodegradable Magnesium Alloys-A Review. Acta Biomater. 2018, 79, 23-36. [CrossRef]

10. Cui, L.Y.; Wei, G.B.; Zeng, R.C.; Li, S.Q.; Zou, Y.H.; Han, E.H. Corrosion resistance of a novel $\mathrm{SnO}_{2}$-doped dicalcium phosphate coating on AZ31 magnesium alloy. Bioact. Mater. 2018, 3, 245-249. [CrossRef]

11. Li, C.Y.; Fan, X.L.; Zeng, R.C.; Cui, L.Y.; Li, S.Q.; Zhang, F.; He, Q.K.; Kannan, M.B.; Jiang, H.W. (George); Chen, D.C.; et al. Corrosion resistance of in-situ growth of nano-sized $\mathrm{Mg}(\mathrm{OH})_{2}$ on micro-arc oxidized magnesium alloy AZ31-Influence of EDTA. J. Mater. Sci. Technol. 2019, 35, 1088-1098. [CrossRef]

12. Robinson, D.A.; Griffith, R.W.; Shechtman, D.; Evans, R.B.; Conzemius, M.G. In vitro antibacterial properties of magnesium metal against Escherichia coli, Pseudomonas aeruginosa and Staphylococcus aureus. Acta Biomater. 2010, 6, 1869-1877. [CrossRef]

13. Feng, H.Q.; Wang, G.M.; Jin, W.H.; Zhang, X.M.; Huang, Y.F.; Gao, A.; Wu, H.; Wu, G.S.; Chu, P.K. Systematic Study of Inherent Antibacterial Properties of Magnesium-based Biomaterials. ACS Appl. Mater. Interfaces 2016, 8, 9662-9673. [CrossRef] [PubMed]

14. Rahim, M.I.; Rohde, M.; Rais, B.; Seitz, J.M.; Mueller, P.P. Susceptibility of Metallic Magnesium Implants to Bacterial Biofilm Infections. J. Biomed. Mater. Res. A 2016, 104, 1489-1499. [CrossRef] [PubMed]

15. Zhang, Y. The in Vitro Biological Properties of Mg-Zn-Sr Alloy and Superiority for Preparation of Biodegradable Intestinal Anastomosis Rings. Med. Sci. Monit. 2014, 20, 1056-1066. [CrossRef] [PubMed]

16. Ren, L.; Lin, X.; Tan, L.L.; Yang, K. Effect of surface coating on antibacterial behavior of magnesium-based metals. Mater. Lett. 2011, 65, 3509-3511. [CrossRef]

17. Zhou, W.C.; Hu, Z.R.; Wang, T.L.; Yang, G.Z.; Xi, W.H.; Gan, Y.Z.; Lu, W.; Hu, J.Z. Enhanced corrosion resistance and bioactivity of $\mathrm{Mg}$ alloy modified by Zn-doped nanowhisker hydroxyapatite coatings. Colloids Surf. $B$ Biointerfaces 2019, 186, 110710. [CrossRef]

18. Zou, Y.H.; Wang, J.; Cui, L.Y.; Zeng, R.C.; Wang, Q.Z.; Han, Q.X.; Qiu, J.; Chen, X.B.; Chen, D.C.; Guan, S.K.; et al. Corrosion resistance and antibacterial activity of zinc-loaded montmorillonite coatings on biodegradable magnesium alloy AZ31. Acta Biomater. 2019, 98, 196-214. [CrossRef]

19. Ji, X.J.; Gao, L.; Liu, J.C.; Wang, J.; Cheng, Q.; Li, J.P.; Li, S.Q.; Zhi, K.Q.; Zeng, R.C.; Wang, Z.L. Corrosion resistance and antibacterial properties of hydroxyapatite coating induced by gentamicin-loaded polymeric multilayers on magnesium alloys. Colloids Surf. B Biointerfaces 2019, 179, 429-436. [CrossRef]

20. Song, J.Q.; Jin, P.L.; Li, M.Q.; Liu, J.G.; Wu, D.M.; Yao, H.T.; Wang, J.Q. Antibacterial properties and biocompatibility in vivo and vitro of composite coating of pure magnesium ultrasonic micro-arc oxidation phytic acid copper loaded. J. Mater. Sci. Mater. Med. 2019, 30, 49-62. [CrossRef]

21. Ji, X.J.; Cheng, Q.; Wang, J.; Zhao, Y.B.; Han, Z.Z.; Zhang, F.; Li, S.Q.; Zeng, R.C.; Wang, Z.L. Corrosion resistance and antibacterial effects of hydroxyapatite coating induced by polyacrylic acid and gentamicin sulfate on magnesium alloy. Front. Mater. Sci. 2019, 13, 87-98. [CrossRef]

22. Zhuk, I.; Jarivala, F.; Attygalle, A.B.; Wu, Y.; Libera, M.R.; Sukhishvili, S.A. Self-Defensive Layer-by-Layer Films with Bacteria-Triggered Antibiotic Release. ACS Nano 2014, 8, 7733-7745. [CrossRef] [PubMed]

23. Onuma, Y.; Serruys, P.W. Bioresorbable scaffold: The advent of a new era in percutaneous coronary and peripheral revascularization? Circulation 2011, 123, 779-797. [CrossRef] [PubMed]

24. Rezk, A.I.; Sasikala, A.R.; Nejad, A.G.; Mousa, H.M.; Oh, Y.M.; Park, C.H.; Kim, C.S. Strategic design of a Musselinspired in situ reduced Ag/Au Nanoparticle Coated Magnesium Alloy for enhanced viability, antibacterial property and decelerated corrosion rates for degradable implant applications. Sci. Rep. 2019, 9, 117. [CrossRef] [PubMed]

25. Zeng, R.C.; Liu, L.J.; Li, S.Q.; Zou, Y.H.; Zhang, F.; Yang, Y.N.; Cui, H.Z.; Han, E.H. Self-assembled silane film and silver nanoparticles coating on magnesium alloys for corrosion resistance and antibacterial applications. Acta Metall. Sin. 2013, 26, 681-686. [CrossRef] 
26. Shao, Y.; Zeng, R.C.; Li, S.Q.; Cui, L.Y.; Zou, Y.H.; Guan, S.K.; Zheng, Y.F. Advance in Antibacterial Magnesium Alloys and Surface Coatings on Magnesium Alloys: A Review. Acta Metall. Sin. Engl. Lett. 2020, 33, 615-629. [CrossRef]

27. Zeng, R.C.; Cui, L.Y.; Jiang, K.; Liu, R.; Zhao, B.D.; Zheng, Y.F. In Vitro Corrosion and Cytocompatibility of a Microarc Oxidation Coating and Poly (L-lactic acid) Composite Coating on Mg-1Li-1Ca Alloy for Orthopaedic Implants. Acs Appl. Mater. Interfaces 2016, 8, 10014-10028. [CrossRef]

28. El-Kamel, R.S.; Ghoneim, A.A.; Fekry, A.M. Electrochemical, biodegradation and cytotoxicity of graphene oxide nanoparticles/polythreonine as a novel nano-coating on AZ91E Mg alloy staple in gastrectomy surgery. Materials Science Eng. C 2019, 103, 109780. [CrossRef]

29. Huang, J.; Xiong, J.; Liu, J.; Zhu, W.; Chen, J.; Duan, L.; Zhang, J.; Wang, D. Evaluation of the novel three-dimensional porous poly (L-lactic acid)/nano-hydroxyapatite composite scaffold. Bio-Med. Mater. Eng. 2015, 26, S197-S205. [CrossRef]

30. Perkins, J.; Xu, Z.G.; Smith, C.; Roy, A.; Kumta, P.N.; Waterman, J.; Conklin, D.; Desai, S. Direct writing of polymeric coatings on magnesium alloy for tracheal stent applications. Ann. Biomed. Eng. 2015, 43, 1158-1165. [CrossRef]

31. Zhao, C.; Hou, P.; Ni, J.; Han, P.; Chai, Y.; Zhang, X. Ag-incorporated FHA Coating on Pure Mg: Degradation and in Vitro Antibacterial Properties. ACS Appl. Mater. Interfaces 2016, 8, 5093-5103. [CrossRef] [PubMed]

32. Tian, J.H.; Shen, S.; Zhou, C.R.; Dang, X.L.; Jiao, Y.P.; Li, L.H.; Ding, S.; Li, H. Investigation of the antimicrobial activity and biocompatibility of magnesium alloy coated with HA and antimicrobial peptide. J. Mater. Sci. Mater. Med. 2015, 26, 66. [CrossRef] [PubMed]

33. Plaass, C.; Ettinger, S.; Sonnow, L.; Koenneker, S.; Noll, Y.; Weizbauer, A.; Reifenrath, J.; Claassen, L.; Daniilidis, K.; Stukenborg-Colsman, C.; et al. Early Results Using a Biodegradable Magnesium Screw for Modified Chevron Osteotomies. J. Orthop. Res. 2016, 34, 2207-2214. [CrossRef] [PubMed]

34. Campoccia, D.; Montanaro, L.; Arciola, C.R. A review of the clinical implications of anti-infective biomaterials and infection-resistant surfaces. Biomaterials 2013, 34, 8018-8029. [CrossRef] [PubMed]

35. Darouiche, R.O. Treatment of Infections Associated with Surgical Implants. N. Engl. J. Med. 2004, 350, 1422-1429. [CrossRef] [PubMed]

36. Monje, A.; Catena, A.; Borgnakke, W.S. Association between Diabetes Mellitus/Hyperglycemia and Peri-Implant Diseases: Systematic Review and Meta-Analysis. J. Clin. Periodontol. 2017, 44, 636-648. [CrossRef] [PubMed]

37. De Oliveira, P.G.F.P.; Bonfante, E.A.; Bergamo, E.T.P.; De Souza, S.L.S.; Riella, L.; Torroni, A.; Jalkh, E.B.B.; Witek, L.; Lopez, C.D.; Zambuzzi, W.F.; et al. Obesity/Metabolic Syndrome and Diabetes Mellitus on Peri-implantitis. Trends Endocrinol. Metab. 2020, 31, 596-610. [CrossRef]

38. Waksman, R.; Erbel, R.; Mario, C.D.; Bartunek, J.; De Bruyne, B.; Eberli, F.R.; Erne, P.; Haude, M.; Horrigan, M.; Ilsley, C.; et al. Early and long-term intravascular ultrasound and angiographic findings after bioabsorbable magnesium stent implantation in human coronary arteries. JACC Cardiovasc. Interv. 2009, 2, 312-320. [CrossRef]

39. Hou, P.; Zhao, C.L.; Cheng, P.F.; Wu, H.L.; Ni, J.H.; Zhang, S.X.; Lou, T.F.; Wang, C.Y.; Han, P.; Zhang, X.N.; et al. Reduced antibacterial property of metallic magnesium in vivo. Biomed. Mater. 2017, 12, 015010. [CrossRef]

40. Zhang, D.; Han, Q.; Yu, K.; Lu, X.P.; Liu, Y.; Lu, Z.; Wang, Q. Antibacterial activities against Porphyromonas gingivalis and biological characteristics of copper-bearing PEO coatings on magnesium. J. Mater. Sci. Technol. 2020, 61, 33-45. [CrossRef]

41. Bakhsheshi-Rad, H.R.; Ismail, A.F.; Aziz, M.; Akbari, M.; Hadisi, Z.; Khoshnava, S.M.; Pagan, E.; Chen, M.B. Co-incorporation of graphene oxide/silver nanoparticle into poly-L-lactic acid fibrous: A route toward the development of cytocompatible and antibacterial coating layer on magnesium implants. Mater. Sci. Eng. C Mater. Biol. Appl. 2020, 111, 110812. [CrossRef] [PubMed]

42. Waksman, R. Bioresorbable scaffolds are here, please handle with care. Cardiovasc. Revasc. Med. 2016, 17, 363-364. [CrossRef] [PubMed]

43. Haude, M.; Erbel, R.; Erne, P.; Verheye, S.; Degen, H.; Bose, D.; Vermeersch, P.; Wijnbergen, I.; Weissman, N.; Prati, F.; et al. Safety and performance of the drug-eluting absorbable metal scaffold (DREAMS) in patients with de-novo coronary lesions: 12 month results of the prospective, multicenter, first-in-man BIOSOLVE-I trial. Lancet 2013, 381, 836-844. [CrossRef] 
44. Haude, M.; Ince, H.; Abizaid, A.; Toelg, R.; Lemos, P.; Birgelen, C.; Christiansen, E. Safety and performance of the drug-eluting absorbable metal scaffold (DREAMS) in patients with de-novo coronary lesions: 6 month results of the prospective, multicenter, first-in-man BIOSOLVE-II trial. Lancet 2016, 387, 31-39. [CrossRef]

45. Ma, J.; Zhao, N.; Zhu, D.H. Sirolimus-eluting dextran and polyglutamic acid hybrid coatings on AZ31 for stent applications. J. Biomater. Appl. 2015, 30, 579-588. [CrossRef]

46. Kozerski, S.; Pawlowski, L.; Jaworski, R.; Roudet, F.; Petit, F. Two zones microstructure of suspension plasma sprayed hydroxyapatite coatings. Surf. Coat. Technol. 2010, 204, 1380-1387. [CrossRef]

47. Yin, Z.Z.; Qi, W.C.; Zeng, R.C.; Chen., X.B.; Gu, C.D.; Guan, S.K.; Zheng, Y.F. Advances in coatings on biodegradable magnesium alloys. J. Magnes. Alloy 2020, 8, 42-65. [CrossRef]

48. Lu, X.; Zhao, Z.; Leng, Y. Biomimetic calcium phosphate coatings on nitric-acid-treated titanium surfaces. Mater. Sci Eng. 2007, 27, 700-708. [CrossRef]

49. Griffith, L.G. Polymeric Biomaterials. Acta Mater. 2000, 48, 263-277. [CrossRef]

50. Yang, Y.; Michalczyk, C.; Singer, F.; Virtanen, S.; Boccaccini, A. In Vitro Study of Polycaprolactone/bioactive Glass Composite Coatings on Corrosion and Bioactivity of Pure Mg. Appl. Surf. Sci. 2015, 355, 832-841. [CrossRef]

51. Xu, L.; Yamamoto, A. Characteristics and Cytocompatibility of Biodegradable Polymer Film on Magnesium by Spin Coating. Colloids Surf. B. Biointerfaces 2012, 93, 67-74. [CrossRef] [PubMed]

52. Acharya, G.; Park, K. Mechanisms of controlled drug release from drug-eluting stents. Adv. Drug Deliv. Rev. 2006, 58, 387-401. [CrossRef] [PubMed]

53. Chen, M.C.; Liang, H.F.; Chiu, Y.L.; Chang, Y.; Wei, H.J.; Sung, H.W. A novel drug-eluting stent spray-coated with multi-layers of collagen and sirolimus. J. Control. Release 2005, 108, 178-189. [CrossRef]

54. Lee, S.J.; Oh, S.H.; Liu, J.; Soker, S.; Atala, A.; Yoo, J.J. The use of thermal treatments to enhance the mechanical properties of electrospun poly( $\epsilon$-caprolactone) scaffolds. Biomaterials 2008, 29, 1422-1430. [CrossRef] [PubMed]

55. Soppimath, K.S.; Aminabhavi, T.M.; Kulkarni, A.R.; Walter, E.R. Biodegradable polymeric nanoparticles as drug delivery devices. J. Control. Release 2001, 70, 1-20. [CrossRef]

56. Patra, S.N.; Easteal, A.J.; Bhattacharyya, D. Parametric study of manufacturing poly (lactic) acid nanofibrous mat by electrospinning. J. Mater. Sci. 2009, 44, 647-654. [CrossRef]

57. Virto, M.R.; Frutos, P.; Torrado, S.; Frutos, G. Gentamicin release from modified acrylic bone cements with lactose and hydroxypropylmethylcellulose. Biomaterials 2003, 24, 79-87. [CrossRef]

58. Zhao, Y.B.; Chen, X.Y.; Li, S.Q.; Zeng, R.C.; Zhang, F.; Wang, Z.L.; Guan, S.K. Corrosion resistance and drug release profile of gentamicin-loaded polyelectrolyte multilayers on magnesium alloys: Effects of heat treatment. J. Colloid Interface Sci. 2019, 547, 309-317. [CrossRef]

59. Janeesh, P.A.; Sami, H.; Dhanya, C.R.; Sivakumar, S.; Avraham, A. Biocompatibility and genotoxicity studies of polyallylamine hydrochloride nanocapsules in rats. RSC Adv. 2014, 4, 24484-24497. [CrossRef]

60. Lei, L.; Hsieh, Y.L. Ultra-fine polyelectrolyte hydrogel fibres from poly (acrylic acid)/poly (vinyl alcohol). Nanotechnology 2005, 16, 2852-2860. [CrossRef]

61. Xu, Q.W.; Li, X.; Jin, Y.Y.; Sun, L.; Ding, X.X.; Liang, L.; Wang, L.; Nan, K.H.; Ji, J.; Chen, H. Bacterial self-defense antibiotics release from organic-inorganic hybrid multilayer films for long-term anti-adhesion and biofilm inhibition properties. Nanoscale 2017, 9, 19245-19254. [CrossRef] [PubMed]

62. Li, Q.Y.; Jiang, G.F.; Wang, D.; Wang, H.; Ding, L.; He, G. Porous magnesium loaded with gentamicin sulphate and in vitro release behavior. Mater. Sci. Eng. C Mater. 2016, 69, 154-159. [CrossRef]

63. Xu, W.; Yagoshi, K.; Koga, Y.; Sasaki, M.; Niidome, T. Optimized polymer coating for magnesium alloy-based bioresorbable scaffolds for long-lasting drug release and corrosion resistance. Colloids Surf. B Biointerfaces 2018, 163, 100-106. [CrossRef] [PubMed]

64. Shi, Y.J.; Zhang, L.; Chen, J.H.; Zhang, J.; Yuan, F.; Shen, L.; Chen, C.X.; Pei, J. In vitro and in vivo degradation of rapamycin-eluting Mg-Nd-Zn-Zr alloy stents in porcine coronary arteries. Mater. Sci. Eng. C 2017, 80, 1-6. [CrossRef]

65. Dayaghi, E.; Bakhsheshi-Rad, H.R.; Hamzah, E.; Akhavan-Farid, A.; Ismail, A.F.; Aziz, M.; Abdolahi, E. Magnesium-zinc scaffold loaded with tetracycline for tissue engineering application: In vitro cell biology and antibacterial activity assessment. Mater. Sci. Eng. C 2019, 102, 53-65. [CrossRef] 
66. Zhao, Y.B.; Shi, L.Q.; Ji, X.J.; Li, J.C.; Han, Z.Z.; Li, S.Q.; Zeng, R.C.; Zhang, F.; Wang, Z.L. Corrosion resistance and antibacterial properties of polysiloxane modified layer-by-layer assembled self-healing coating on magnesium alloy. J. Colloid Interface Sci. 2018, 526, 43-50. [CrossRef]

67. Yang, Y.Y.; Zheng, K.; Liang, R.F.; Mainka, A.; Taccardi, N.; Roether, J.A.; Detsch, R.; Goldmann, W.H.; Virtanen, S.; Boccaccini, A.R. Cu-releasing BG/PCL Coating on Mg with Antibacterial and Anticorrosive Properties for Bone Tissue Engineering. Biomed. Mater. 2017, 13, 015001. [CrossRef]

68. Rau, J.V.; Curcio, M.; Raucci, M.G.; Barbaro, K.; Fasolino, I.; Teghil, R.; Ambrosio, L.; Bonis, A.D.; Boccaccini, A.R. $\mathrm{Cu}$-releasing bioactive glass coatings and their in vitro properties. ACS Appl. Mater. Interfaces 2019, 11, 5812-5820. [CrossRef]

69. Geng, Z.; Cui, Z.D.; Li, Z.Y.; Zhu, S.L.; Liang, Y.Q.; Liu, Y.D.; Li, X.; He, X.; Yu, X.X.; Wang, R.F.; et al. Strontium Incorporation to Optimize the Antibacterial and Biological Characteristics of Silver-Substituted Hydroxyapatite Coating. Mater. Sci. Eng. C. 2016, 58, 467-477. [CrossRef]

70. Cho, K.H.; Park, J.E.; Osaka, T.; Park, S.G. The Study of Antimicrobial Activity and Preservative Effects of Nanosilver Ingredient. Eletrochim. Acta 2005, 51, 956-960. [CrossRef]

71. Rai, M.; Yadav, A.; Gade, A. Silver Nanoparticles as a New Generation of Antimicrobials. Biotechnol. Adv. 2009, 27, 76-83. [CrossRef] [PubMed]

72. Jamuna-Thevi, K.; Bakar, S.A.; Ibrahim, S.; Shahab, N.; Toff, M.R.M. Quantification of silver ion release, in vitro cytotoxicity and antibacterial properties of nanostuctured $\mathrm{Ag}$ doped $\mathrm{TiO}_{2}$ coatings on stainless steel deposited by RF magnetron sputtering. Vacuum 2011, 86, 235-241. [CrossRef]

73. Yang, W.J.; Shen, C.C.; Ji, Q.L.; An, H.J.; Wang, J.J.; Liu, Q.D.; Zhang, Z.Z. Food storage material silver nanoparticles interfere with DNA replication fidelity and bind with DNA. Nanotechnology 2009, 20, 085102. [CrossRef] [PubMed]

74. DeVasConCellos, P.; Bose, S.; Beyenal, H.; Bandyopadhyay, A.; Zirkle, L.G. Antimicrobial Particulate Silver Coatings on Stainless Steel Implants for Fracture Management. Mater. Sci. Eng. C 2012, 32, 1112-1120. [CrossRef] [PubMed]

75. Zille, A.; Fernandes, M.M.; Francesko, A.; Tzanov, T.; Fernandes, M.; Oliveira, F.R.; Almeida, L.; Amorim, T.; Almeida, L.; Amorim, T.; et al. Size and Aging Effects on Antimicrobial Efficiency of Silver Nanoparticles Coated on Polyamide Fabrics Activated by Atmospheric DBD Plasma. ACS Appl. Mater. Interfaces 2015, 7, 13731-13744. [CrossRef] [PubMed]

76. Tan, L.; Wang, Q.; Lin, X.; Wan, P.; Zhang, G.; Zhang, Q.; Yang, K. Loss of mechanical properties in vivo and bone-implant interface strength of AZ31B magnesium alloy screws with Si-containing coating. Acta Biomater. 2014, 10, 2333-2340. [CrossRef]

77. Hans, M.; Mathwes, S.; Mucklich, F.; Solioz, M. Physicochemical properties of copper important for its antibacterial activity and development of a unified model. Biointerphases 2015, 11, 018902. [CrossRef]

78. Yang, G.Z.; Yang, H.W.; Shi, L.; Wang, T.L.; Zhou, W.C.; Zhou, T.; Han, W.; Zhang, Z.Y.; Lu, W.; Hu, J.Z. Enhancing corrosion resistance, osteoinduction, and antibacterial properties by $\mathrm{Zn} / \mathrm{Sr}$ additional surface modification of magnesium alloy. ACS Biomater. Sci. Eng. 2018, 4, 4289-4298. [CrossRef]

79. Guo, Y.T.; Jia, S.Q.; Qiao, L.; Su, Y.C.; Gu, R.; Li, G.Y.; Lian, J.S. A multifunctional polypyrrole/zinc oxide composite coating on biodegradable magnesium alloys for orthopedic implants. Colloids Surf. B Biointerfaces 2020, 194, 111186. [CrossRef]

80. Salem, W.; Leitner, D.R.; Zingl, F.G.; Schratter, G.; Prassl, R.; Goessler, W.; Reidl, J.; Schild, S. Antibacterial activity of silver and zinc nanoparticles against Vibrio cholerae and enterotoxic Escherichia coli. Int. J. Med. Microbiol. 2015, 305, 85-95. [CrossRef]

81. Pati, R.; Mehta, R.K.; Mohanty, S.; Padhi, A.; Sengupta, M.; Vaseeharan, B.; Goswami, C.; Sonawane, A. Topical application of zinc oxide nanoparticles reduces bacterial skin infection in mice and exhibits antibacterial activity by inducing oxidative stress response and cell membrane disintegration in macrophages. Nanomedicine: Nanotechnology. Biol. Med. 2014, 10, 1195-1208. [CrossRef] [PubMed]

82. Liu, W.W.; Su, P.L.; Chen, S.; Wang, N.; Ma, Y.P.; Liu, Y.R.; Wang, J.S.; Zhang, Z.T.; Li, H.Y.; Webster, T.J. Synthesis of $\mathrm{TiO}_{2}$ nanotubes with $\mathrm{ZnO}$ nanoparticles to achieve antibacterial properties and stem cell compatibility. Nanoscale 2014, 6, 9050-9062. [CrossRef] [PubMed]

83. Yu, F.; Fang, X.; Jia, H.M.; Liu, M.X.; Shi, X.T.; Xue, C.W.; Chen, T.T.; Wei, Z.P.; Fang, F.; Zhu, H.; et al. Zn or O? An Atomic Level Comparison on Antibacterial Activities of Zinc Oxides. Chemistry 2016, 22, 8053-8058. [CrossRef] [PubMed] 
84. Joe, A.; Park, S.H.; Kim, D.J.; Lee, Y.J.; Jhee, K.H.; Sohn, Y.K.; Jang, E.S.; Jang, E.S. Antimicrobial activity of $\mathrm{ZnO}$ nanoplates and its Ag nanocomposites: Insight into an ROS-mediated antibacterial mechanism under UV light. J. Solid. State. Chem. 2018, 267, 124-133. [CrossRef]

85. Ding, X.; Yang, C.; Lim, T.P.; Hsu, L.Y.; Engler, A.C.; Hedrick, J.L.; Yang, Y.Y. Antibacterial and antifouling catheter coatings using surface grafted peg-b-cationic polycarbonate deblock copolymers. Biomaterials 2012, 33, 6593-6603. [CrossRef] [PubMed]

86. Jiang, R.; Xin, Z.; Xu, S.; Shi, H.; Yang, H.; Song, L.; Yan, S.; Luan, S.; Yin, J.; Khan, A.F.; et al. Enzyme-mimicking polymer brush-functionalized surface for combating biomaterial-associated infections. Appl. Surf. Sci. 2017, 423, 869-880. [CrossRef]

87. Wang, C.; Ma, C.; Mu, C.; Lin, W. A novel approach for synthesis of zwitterionic polyurethane coating with protein resistance. Langmuir 2014, 30, 12860-12867. [CrossRef]

88. Luo, L.; Li, G.; Luan, D.; Yuan, Q.; Wei, Y.; Wang, X. Antibacterial adhesion of borneol-based polymer via surface chiral stereochemistry. ACS Appl. Mater. Interfaces 2014, 6, 19371-19377. [CrossRef]

89. Wang, C.H.; Yi, Z.L.; Sheng, Y.F.; Tian, L.; Qin, L.; Ngai, T.; Lin, W. Development of a novel biodegradable and anti-bacterial polyurethane coating for biomedical magnesium rods. Mater. Sci. Eng. C 2019, 99, $344-356$. [CrossRef]

90. Sun, J.D.; Zhu, Y.; Meng, L.; Chen, P.; Shi, T.T.; Liu, X.Y.; Zheng, Y.F. Electrophoretic deposition of colloidal particles on $\mathrm{Mg}$ with cytocompatibility, antibacterial performance, and corrosion resistance. Acta Biomater. 2016, 45, 387-398. [CrossRef]

91. Mai, L.M.; Lin, C.Y.; Chen, C.Y.; Tsai, Y.C. Synergistic effect of bismuth subgallate and borneol, the major components of sulbogin ${ }^{\circledR}$, on the healing of skin wound. Biomaterials 2003, 24, 3005-3012. [CrossRef]

92. Bertuola, M.; Miñán, A.; Grillo1, C.A.; Cortizo, M.C.; De Mele, M.A.F.L. Corrosion protection of AZ31 alloy and constrained bacterial adhesion mediated by a polymeric coating obtained from a phytocompound. Colloids Surf. B Biointerfaces 2018, 172, 187-196. [CrossRef]

93. Yao, Z.; Li, L.; Jiang, Z. Adjustment of the ratio of $\mathrm{Ca} / \mathrm{P}$ in the ceramic coating on $\mathrm{Mg}$ alloy by plasma electrolytic oxidation. Appl. Surf. Sci. 2009, 255, 6724-6728. [CrossRef]

94. Liu, G.Y.; Hu, J.; Ding, Z.K.; Wang, C. Bioactive calcium phosphate coating formed on micro-arc oxidized magnesium by chemical deposition. Appl. Surf. Sci. 2011, 257, 2051-2057. [CrossRef]

95. Simchen, F.; Sieber, M.; Kopp, A.; Lampke, T. Introduction to Plasma Electrolytic Oxidation-An Overview of the Process and Applications. Coatings 2020, 10, 628. [CrossRef]

96. Chen, J.X.; Zhang, Y.; Ibrahima, M.; Etim, I.P.; Tan, L.L.; Yang, K. In vitro degradation and antibacterial property of a copper-containing microarc oxidation coating on Mg-2Zn-1Gd-0.5Zr alloy. Colloids Surf. $B$ Biointerfaces 2019, 179, 77-86. [CrossRef]

97. Tian, P.; Xu, D.M.; Liu, X.Y. Mussel-inspired functionalization of PEO/PCL composite coating on a biodegradable AZ31 magnesium alloy. Colloids Surf. B Biointerfaces 2016, 141, 327-337. [CrossRef]

98. Takagi, S.; Chow, L.C.; Ishikawa, K. Formation of hydroxyapatite in new calcium phosphate cements. Biomaterials 1998, 19, 1593-1599. [CrossRef]

99. Ramselaar, M.M.A.; Driessens, F.C.M.; Kalk, W.; De Wijn, J.R.; Van Mullen, P.J. Biodegradation of four calcium phosphate ceramics: In vivo rates and tissue interactions. J. Mater. Sci. Mater. Med. 1991, 2, 63-70. [CrossRef]

100. Coelho, P.G.; Assis, S.L.D.; Costa, I.; Van Thompson, P.V. Corrosion resistance evaluation of a Ca-and P-based bioceramic thin coating in Ti-6Al-4V. J. Mater. Sci. Mater. Med. 2009, 20, 215-222. [CrossRef]

101. Sridhar, T.M.; Mudali, U.K.; Subbaiyan, M. Preparation and characterisation of electrophoretically deposited hydroxyapatite coatings on type 316 L stainless steel. Corros. Sci. 2003, 45, 237-252. [CrossRef]

102. Tan, C.; Zhang, X.X.; Li, Q. Fabrication of multifunctional CaP-TC composite coatings and the corrosion protection they provide for magnesium alloys. Biomed. Eng. 2017, 62, 375-381. [CrossRef]

103. Tesavibul, P.; Chantaweroad, S.; Laohaprapanon, A.; Channasanon, S.; Uppanan, P.; Tanodekaew, S.; Chalermkarnnon, P.; Sitthiseripratip, K. Biocompatibility of hydroxyapatite scaffolds processed by lithography-based additive manufacturing. Bio-Med. Mater. Eng. 2015, 26, 31-38. [CrossRef]

104. Ozeki, K.; Goto, T.; Aoki, H.; Masuzawa, T. Influence of the crystallinity of a sputtered hydroxyapatite film on its osteocompatibility. Bio-Med. Mater. Eng. 2015, 26, 139-147. [CrossRef] 
105. Predoi, D.; Iconaru, S.L.; Predoi, M.V.; Motelica-Heino, M.; Buton, N.; Megier, C. Obtaining and Characterizing Thin Layers of Magnesium Doped Hydroxyapatite by Dip Coating Procedure. Coatings 2020, 10, 510. [CrossRef]

106. Pang, K.M.; Lee, J.K.; Seo, Y.K.; Kim, S.M.; Kim, M.J.; Lee, J.H. Biologic properties of nano-hydroxyapatite: An in vivo study of calvarial defects, ectopic bone formation and bone implantation. Bio-Med. Mater. Eng. 2015, 25, 25-38. [CrossRef]

107. Tan, F.; Naciri, M. Al-Rubeai, M. Osteoconductivity and growth factor production by MG63 osteoblastic cells on bioglass-coated orthopedic implants. Biotechnol. Bioeng. 2011, 108, 454-464. [CrossRef]

108. Bai, N.N.; Tan, C.; Li, Q.; Xi, Z.X. Study on the corrosion resistance and anti-infection of modified magnesium alloy. Biomed. Mater. Eng. 2017, 28, 339-345. [CrossRef]

109. Wang, B.; Zhao, L.; Zhu, W.W.; Fang, L.M.; Ren, F.Z. Mussel-inspired nano-multilayered coating on magnesium alloys for enhanced corrosion resistance and antibacterial property. Colloids Surf. B Biointerfaces 2017, 157, 432-439. [CrossRef]

110. Zasloff, M. Antimicrobial peptides of multicellular organisms. Nature 2002, 415, 389-395. [CrossRef]

111. DeSmet, K.; Contreras, R. Human antimicrobial peptides: Defensins, cathelicidins and histatins. Biotechnol. Lett. 2005, 27, 1337-1347. [CrossRef]

112. Kazemzadeh-Narbat, M.; Noordin, S.; Masri, B.A.; Garbuz, D.S.; Duncan, C.P.; Hancock, R.E.W.; Wang, R.Z. Drug release and bone growth studies of antimicrobial peptide-loaded calcium phosphate coating on titanium. J. Biomed. Mater. Res. Part. B 2012, 100, 1344-1352. [CrossRef]

113. Janning, C.; Willbold, E.; Vogt, C.; Nellesen, J.; Meyer-Linderberg, A.; Windhagen, H.; Thorey, F.; Witte, F. Magnesium hydroxide temporarily enhancing osteoblast activity and decreasing the osteoclast number in peri-implant bone remodeling. Acta Biomater. 2010, 6, 1861-1868. [CrossRef]

114. Ratner, B.D.; Hoffman, A.S.; Schoen, F.J.; Lemons, J.E. Biomaterials Science: An Introduction to Materials in Medicine; Elsevier Academic Press: New York, NY, USA, 2004; pp. 10-11.

115. Poinern, G.E.J.; Brundavanam, S.; Fawcett, D. Biomedical Magnesium Alloys: A Review of Material Properties, Surface Modifications and Potential as a Biodegradable Orthopedic Implant. Am. J. Biomed. Eng. 2012, 2, 218-240. [CrossRef]

116. Song, G.L.; Atren, A. Corrosion Mechanisms of Magnesium Alloys. Adv. Eng. Mater. 1999, 1, 11-33. [CrossRef]

117. Kraus, T.; Fischerauer, S.F.; Hänzi, A.C.; Uggowitzer, P.J.; Löffler, J.F.; Weinberg, A.M. Magnesium alloys for temporary implants in osteosynthesis: In vivo studies of their degradation and interaction with bone. Acta Biomater. 2012, 8, 1230-1238. [CrossRef]

118. Witte, F.; Hort, N.; Vogt, C.; Cohen, S.; Kainer, K.U.; Willumeit, R.; Feyerabend, F. Degradable biomaterials based on magnesium corrosion. Curr. Opin. Solid State Mater. Sci. 2008, 12, 63-72. [CrossRef]

119. Walker, J.; Shadanbaz, S.; Kirkland, N.T.; Stace, E.; Woodfield, T.; Staiger, M.P.; Dias, G.J. Magnesium alloys: Predicting in vivo corrosion with in vitro immersion testing. J. Biomed. Mater. Res. Part. B Appl. Biomater. 2012, 100, 1134-1141. [CrossRef]

(C) 2020 by the authors. Licensee MDPI, Basel, Switzerland. This article is an open access article distributed under the terms and conditions of the Creative Commons Attribution (CC BY) license (http://creativecommons.org/licenses/by/4.0/). 